$\begin{array}{cc}\text { Türk Coğrafya Dergisi } & \text { Turkish Geographical Review } \\ & \text { www.tcd.org.tr }\end{array}$

\title{
Boğatepe Köyü'nde Gravyer peyniri üretimi ve sürdürülebilir gelişme bakımından önemi (Kars/Türkiye)
}

\section{The Gruyere cheese production in Bogatepe Village and its importance in terms of sustainable development (Kars/Turkey)}

\author{
Kenan Arınç*a \\ ${ }^{a}$ Atatürk Üniversitesi, Edebiyat Fakültesi, Coğrafya Bölümü, Erzurum.
}

\section{BILGI / INFO}

Geliş/Received: 07.11.2017

Kabul/Accepted: 27.01.2018

Anahtar Kelimeler:

Gravyer peyniri

Boğatepe

Malakanlar

Doukhoborlar

Zavot

\section{Keywords:}

Gruyere cheese

Bogatepe - Kars

Molokans

Doukhobors

Zavod

*Sorumlu yazar/Corresponding author:

(K. Arınç) karinc@atauni.edu.tr

\section{DOI: $19.17211 /$ tcd.349760}

\section{Atff/Citation:}

Arınç, K. (2018). Boğatepe Köyü'nde Gravyer peyniri üretimi ve sürdürülebilir gelişme bakımından önemi (Kars/Türkiye). Türk Coğrafya Dergisi (70), 7-18. DOI:19.17211/tcd.349760.

\section{ÖZ / ABSTRACT}

Doğu Anadolu Bölgesi'nde yer alan Kars iline bağlı bir köy yerleşmesi olan Boğatepe, Türkiye'de Gravyer peynirinin ilk üretildiği yer olarak tanınmaktadır. Bu köy Ardahan-Kars Yöresinin 1877-1878 Osmanlı-Rus savaşı sırasında Rusların eline geçmesi nedeniyle Rusya'dan göç ettirilen Malakanlar ve Doukhoborların yerleşmesi için kurulmuş ve Büyük Zavot adını almıştı. Yörenin ekolojisinin hayvancılığa ve gravyer peyniri üretimine elverişli olduğu anlaşıınca Rusların daveti üzerine İsviçreli peynir üreticisi David Moser, ilk gravyer atölyesini Boğatepe köyünde kurmuştu. Kısa sürede yörenin diğer köylerine de yayılan Gravyer peyniri atölyelerinin sayısı 50'ye yükselmişti. Rus işgalinin sona ermesiyle birlikte kolonistlerin Türkiye'den ayrılması nedeniyle Ardahan-Kars Yöresinde atölye sayısı sürekli azalmıştr. Nitekim halen faal olan imalathane sayısı Boğatepe köyünde 2 ve Kars Organize Sanayi Bölgesi'nde 2 olmak üzere toplam 4 adettir. SSCB'nin 1917 yılında kurulması sonucu bu ülkede yaşamak istemeyen ve gravyer üretimine aşina olan Karapapak (Terekeme), Kıpçak, Komuk ve Karakalpak gibi Türk boylarının, 1936 yılında Ardahan-Kars Yöresine yerleştirilmeleri nedeniyle, Boğatepe köyü de nüfuslanmış ve kolonistlerden kalan ekipmanlarla gravyer peyniri üretimi yeniden başlatılmışt. Ancak Boğatepe köyünün, 1975 yılından sonra göç vermeye başlaması nedeniyle gravyer üretimi durmuştu. Fakat bir gravyer ustasının 2002 yılında Boğatepe köyüne dönmesiyle birlikte üretim yeniden canlandırılmıştır. Günümüzde köy halkının üretim için işbölümünü başarmaları nedeniyle, sağılabilen inek sayısı 4000'e yükselmiştir. O halde katma değeri yüksek olan ve uzmanlık gereken Gravyer peyniri üretimi, yörenin kalkınması ve sürdürülebilir gelişmesi için önem taşımaktadır. Gravyer peynirinin 6 ayı aşan zorlu bir üretim süreci vardır. Elde edilen sütün bir saat içinde üretim sürecine girmesi zorunluluğu nedeniyle gravyer tesisinin 1800 m'den daha yüksekte kurulması ve hayvanların yüksek kuşakta otlatılmaları üretim şartının en önemlisidir. Ardahan-Kars Yöresinde bulunan pek çok kırsal yerleşmenin ekolojisi bu üretim için uygundur. Bu nedenle benzer ekolojiye sahip yerlerin de Gravyer peyniri üretimi için organize edilmeleri kalkınma için gereklidir.

Bogatepe, a village settlement in the province of Kars in the Eastern Anatolia Region, is defined as the place where gruyere cheese was produced for the first time in Turkey. This village was established for the settlement of the Malakans and Doukhobors, who were displaced from Russia, due to the capture of the Ardahan-Kars Province by the Russians during the Ottoman-Russian war of 1877-1878, and named "Büyük Zavot". Since it was concluded that the ecology of the region was appropriate for husbandry and gruyere cheese production, the Scottish cheese producer, David Moser, founded the first gruyere cheese atelier in Bogatepe village at the request of Russians. In a short time, the number of the gruyere cheese ateliers spreading to other villages in the region increased to 50. Following the end of Russian invasion, colonists left Turkey and the number of active ateliers decreased continuously. Today, there are four active ateliers. After the creation of the USSR in 1917, some Turkic people such as Qarapapaqs, Kipchaks, Kumyks and Qaraqalpaqs, who did not want to live in that country and were familiar with gruyere cheese production, were settled in the Ardahan-Kars region in 1936, repopulated Bogatepe village and restarted the gruyere cheese production, using the equipment the colonists left behind. However, as the Bogatepe village began to emigrate after 1975, the gruyere cheese production stopped. Nevertheless, gruyere cheese production revived thanks to a gruyere master coming back to Bogatepe village in 2002. Nowadays, since the village people share tasks successfully, the number of dairy cattles rose to 4000 . In that case, the gruyere cheese, which has high added-value and requires master ship, is essential in terms of development and sustainable advancement of the region. Gruyere cheese has a demanding production process exceeding 6 months. The most prominent rules of production are to install gruyere cheese facilities above $1800 \mathrm{~m}$ and to pasture animals in high zones, since the milk has to enter into the production in 1 hour. The ecology of many rural settlements in Ardahan-Kars region is suitable for this production. Thus, it is necessary for development to organize places with similar ecology for gruyere cheese production. 


\section{Giriş}

Boğatepe, Doğu Anadolu Bölgesi'nin Erzurum-Kars Bölümü'nde olan Kars iline bağlı bir köy yerleşmesidir. Allahuekber Dağları'nın kuzey eteklerinde yer alan bu köy, Kars kentine 40 km ve Ardahan kentine ise 38 km. uzaklıktadır. Kars'tan Göle ve Ardahan'a ulaşan anayol 2344 m. yüksekliğindeki Boğatepe Geçidi'ni aşmak zorundadır. Bu geçit çevresinde olan Boğatepe: Göle, Ardahan, Susuz ve Kars gibi idari merkezlere kolaylıkla erişilebildiğinden, ulaşım avantajı olan bir yerleşmedir (Şekil 1). Boğatepe köyü 1955 yılına kadar Göle ilçesine bağlı bir köy yerleşmesi durumundaydı. Fakat Göle ilçesinin, 1992 yılında oluşturulan Ardahan iline bağlanması sırasında, iki ilin ortak sınırı üzerinde bulunan Boğatepe köyü, Kars ili merkez ilçesi sınırları içine alınmıştı.

Kuzeyinde ve güneyinde yüksek bir dağlık kuşak bulunan köyün hafif eğimlerle yükseklik kazanan bir topoğrafya ile yaz yağışlarına bağlı gür bir vejetasyona sahip olması nedeniyle çevresinde çok fazla yayla yerleşmesi ve geniş mera alanları bunmaktadır. Doğal ortam şartları, Türkiye'nin en önemli hayvancılık alanlarından biri olan Ardahan-Kars yöresinin tam orta kısmında kalan Boğatepe köyünün iktisadi faaliyetlerini olumlu yönde etkilemiştir. Gerçekten de konum avantajı ve doğanın sunduğu imkânlar nedeniyle yörede hayvancılık gelişmiş ve uzmanlık düzeyi yüksek bir hayvansal ürün olan Gravyer peyniri üretimi ortaya çıkmıştır.

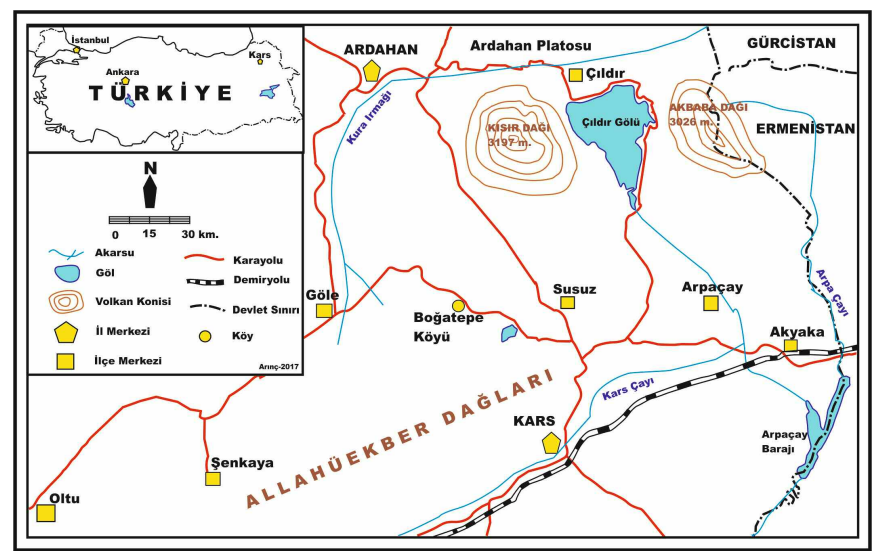

Şekil 1. Boğatepe Köyü ve çevresinin lokasyon haritası.

Figure 1. Location map of Bogatepe Village and its surroundings.

Boğatepe köyü, kurulduğu dönemde kökeni Rusça olan ve fabrika/imalathane anlamını taşıyan Büyükzavot adıyla tanınıyor, yaklaşık $2 \mathrm{~km}$. doğusunda olan başka bir köy ise Küçükzavot adını taşıyordu. Bu iki köyün adı 1936 tarihinde değiştirilerek Büyükboğatepe ve Küçükboğatepe olarak anılmaya başlandı. Her iki köyün yerleşme tarihi oldukça yeni olup 93 Harbi olarak bilinen 1877-1878 Osmanlı-Rus Savaşı sonrasında kurulmuşlardır. Ardahan-Kars Yöresindeki pek çok kırsal yerleşme gibi bu iki köy de Ruslar tarafindan 1880 yılında göç ettirilerek Kars ili topraklarına yerleştirilen azınlıklardan Malakanların yerleştirilmesi amacıyla oluşturulmuştu (Fotoğraf 1).

Rus işgali yıllarında Boğatepe'ye yerleşen bir İsviçreli peynir imalatçısının bu köyde ilk Gravyer peyniri imalathanesi kurması ile Anadolu coğrafyası ilk kez insan sağlığı için çok değerli bir besin kaynağı olan Gravyer peyniri ile tanışmışt. Ardından Ruslar tarafindan bölgeye getirilen İsviçre ve Alman kökenli peynir ustaları, Malakanları ve Doukhoborları Gravyer peyniri üretimi için eğitmeye başlamış ve Ardahan-Kars Yöresi'nde pek çok Gravyer peyniri imalathanesi kurulmuştu. Ekim 1917 Bolşevik ihtilali sırasında Rus ordusunun bölgeden çekilmesinin ardından, Gravyer peyniri üretimi konusundan uzmanlaşmış nüfus da ülke dışına göç etmiş ve bölgenin ekonomik gelişimi için çok önemli olan Gravyer ustalığı bitme noktasına gelmiştir. Buna karşılık o günkü SSCB topraklarında yaşamak istemeyen Kıçaklar, Karapapaklar (Terekemeler), Karakalpaklar, Kumanlar ve Komuklar Ardahan-Kars Yöresi'ne yerleşmeye başlamışt. Bunlardan bir bölümünün daha önce Gravyer peyniri üretimine aşina olmaları, bir kısmının da henüz ülkeden ayrılmamış olan Malakanlardan Gravyer peyniri imalatını öğrenmeleri nedeniyle yabancı gruplardan geriye kalan gravyer atölyelerinde üretimi sürdürmeyi başarabilmiş ve günümüze ulaşmasını sağlamışlardır.

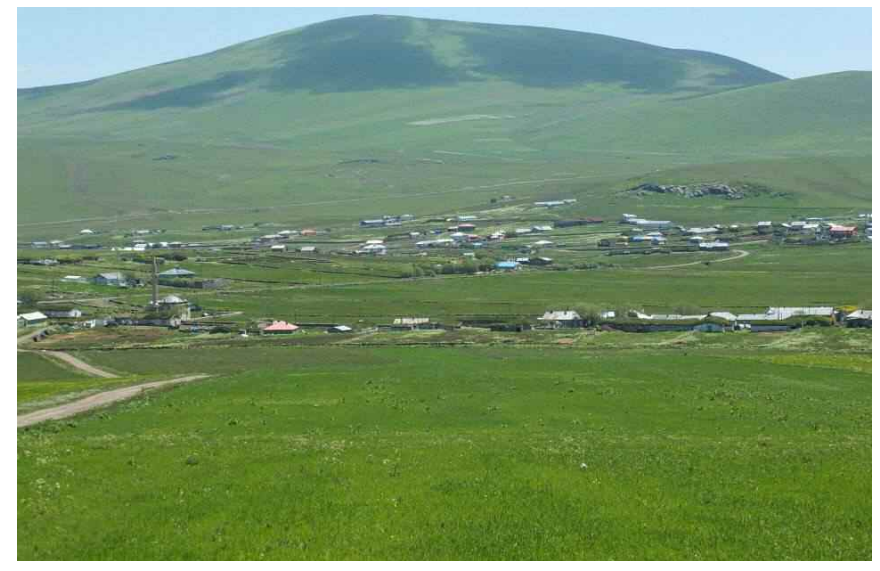

Fotoğraf 1. Boğatepe Köyü’nden genel bir görünüm.

Photo 1. A general view from Bogatepe Village.

Bununla birlikte Anadolu'nun en soğuk kuşağını oluşturan Erzurum-Kars Bölümü'nün tüm kırsal yerleşmelerinin ortak kaderi olarak, yükselti ve iklim şartlarının hayat güçleştirmesi, yaşama maliyetinin yüksekliği ve yeterli gelir elde edilememesi gibi nedenlerle göçler başlamış ve bu köyler boşalmaya başlamıştır. Gravyer peyniri üretimini inatla ve ısrarla sürdüren birkaç aile dışında bu faaliyet sona ermek üzeredir. Dolayısıyla unutulmaya yüz tutmuş ve önemli derecede uzmanlık gerektiren Gravyer peyniri üretiminin, Ardahan-Kars Yöresinde nüfusun göç etmesini önleyici bir ekonomik etkinlik olması nedeniyle, yapısal sorunlarının anlaşılması ve bir an önce çözümlenmesi gerekmektedir.

\section{Amaç ve Metot}

Bilindiği üzere Türkiye 1950 yılından sonra kırsal alanlardan kentlere yoğun ve sürekli göçlerin meydana geldiği bir ülke görünümündedir. Günümüz Türkiye'sinde yirmi bin ve üzerinde nüfusa sahip kentsel yerleşmelerinde yaşayan nüfus oranı \%80'i bulmuştur (2015 yılı itibariyle \%79.4). Dolayısıyla kırsal nüfus oranı \%20'nin altına doğru gerilemeye devam etmektedir. Doğu Anadolu Bölgesi genelinde kırsal nüfus oranı henüz fazla kötüleşmemiş gibi gözükse bile (\%45.8) kırsal nüfus, ülkenin toprakları en geniş olan bu coğrafi bölgesinde üç milyonun altına inmiş durumdadır. Ardahan-Kars Yöresi özeline bakıldığında ise kırsal kesim nüfusunun çok eksilmiş olmasına rağmen, hala daha oran bakımından iyi bir durumda olduğu söylenebilir (kırsal nüfus oranı Ardahan ilinde \%80, Kars ilinde \%72). Fakat bu kez de kentsel nüfusu ve toplam nüfusu az olan bir yöreden 
bahsedildiği için, bu oranların pek fazla anlam ifade etmediği de söylenebilir.

Hangi açıdan bakılırsa bakılsın Doğu Anadolu Bölgesi'nin nüfusunun artması, Türkiye için hayati bir önem taşımaktadır. Türkiye'nin gelecekte komşu ülkelerden gelebilecek tehditleri karşılayacağı ilk yerler, ülke sınırlarına yakın konumlardır. Nüfusu fazla ve nüfus yoğunluğu yüksek bir bölge ise en caydırıcı silah olarak kabul edilir. Çünkü sınırlar, ülkelerin gelişme, değişme doğrultularını ve imajlarının yönünü gösteren sanal çizgilerdir. Sınırlar devletler arasındaki kültür bölgelerinin unsurları olarak ele alınabilir ve coğrafi önemi daha da artabilir (Göney, 1979). Bu gerçekliğe karşın, bölgenin çok büyük bir kesimi ekstansif metotlarla üretim yapmakta ve fakirlik sarmalını kıramamış bulunmaktadırlar. Gelişmenin ana şartlarından biri olan uzmanlaşma ve katma değeri yüksek ürünler elde edebilme şansı, çok az yerde yakalanabilmiştir. Bu yerlerden biri de yabancı bir kültürün getirip coğrafyalarına sunduğu Gravyer peyniri üretimi konusunda uzmanlaşma şansını yakalamış Kars ve Ardahan illeridir. Ancak söz konusu katma değeri yüksek üretimin, nüfus eksilmesinden de anlaşılacağı üzere, uzun vadede korunamayacağı tahmini yapılabilir.

Türkiye'nin ve Doğu Anadolu Bölgesi'nin tanınması, tanıtılması ve değerlendirilmesini konu edinen ve kalkınma çabalarının en etkili yönlendiricilerinden biri olan coğrafya araştırmalarının önemi büyüktür. O halde Boğatepe köyünün ve benzer ekolojide olan diğer kırsal yerleşmelerin sorunlarının anlaşılması ve çözüm önerilerinin sunulması ile kamuoyunun ve uygulayıcı çevrelerin dikkatine sunulması için bu tip coğrafî incelemelere ihtiyaç vardır.

Bu çalışmanın verileri gezi ve gözlem metodu ile bilirkişilerle yapılan mülakat yöntemiyle elde edilmiştir. Ayrıca dedüktif ve endüktif yöntemler kullanılmış ve coğrafyanın dağılım, bağlant ve sebep-sonuç ilkeleri gözetilmek suretiyle analitik değerlendirmeler yapılmıştır.

\section{Bulgular}

\subsection{Boğatepe Köyü'nün Doğal Çevre Özellikleri}

Inceleme konusunu teşkil eden Boğatepe Köyü, Coğrafyacılar tarafindan Ardahan-Kars Yöresi olarak tanımlanmış bir alanda yer alır. Bu alan kuzeyden Yalnızçam Dağları, batıdan Kargapazarı ve Güllü dağları, güneyden Aras Irmağı'nın kuzey kenarı boyunca sıralanan volkanik kökenli tek dağlar dizisi (Süphandağı 2909 m, Balıklı Dağı 2858 m, Aladağ 3138 m. ve Yağlıca Dağı $2961 \mathrm{~m}$ ) ile kuşatılmış bir platolar sahasıdır. Alanın doğusu ise Ermenistan ve Gürcistan sınırlarına dayanmaktadır (Arınç, 2016). Yöre, Kura Irmağı ve Kars Çayı tarafindan yarılmış ve parçalanmıştır. Bu yöreyi kuzeydoğu-güneybat doğrultusunda uzanan Allahüekber Dağları (3120 m), Kısır Dağı ve Akbaba Dağı hemen hemen eşit büyüklükte olan Sarıkamış-Kars ve Göle-Ardahan olmak üzere iki farklı alt yöreye ayırmaktadır.

Boğatepe köyü, Allahuekber Dağlarının Göle Ovası'na bakan kuzey eteklerinde kurulmuştur. Köyün yerleşme alanı kuzey ve güney yönünde yüksek bir relief ile kuşatılmıştır. Arazinin en yüksek kesimini, köyün kuzeydoğusundaki Pliyo-Kuvaterner yaşlı andezitler ve piroklastiklerden oluşan 2732 m. yüksekliğindeki Büyükboğa Tepesi oluşturur. Adeta bir sıradağ görünümünde kuzeydoğu-güneybatı doğrultusunda uzanan Allahuekber Dağlarının zirveleri 3000'yi aşsa da Boğatepe kö- yünü güneyden sınırlayan tepelerin yükseltisi en fazla 2700 m.ye kadar ulaşır. Kars'tan Göle'ye ulaşan ana karayolu Allahüekber Dağları ile Boğatepe arasındaki alçalma alanını izler. Bu alçalma alanın doğusunda 2344 m. yüksekliğindeki Boğatepe Geçidi bulunmaktadır. Bu geçit Kars-Ardahan arasında işleyen yolun ulaşıma güçlük çıkaran bölümünü oluşturur (Şekil 2).

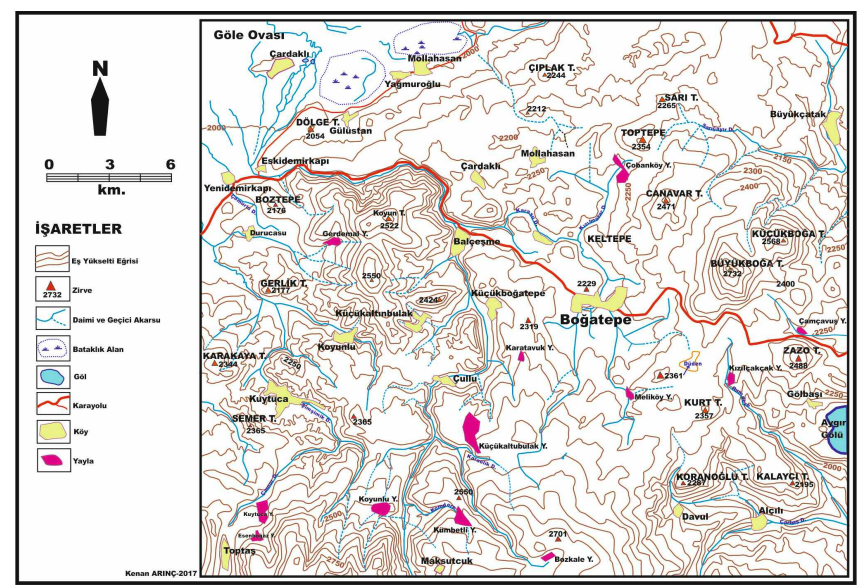

Şekil 2. Boğatepe Köyü ve çevresinin topoğrafya haritası.

Figure 2. Topographical map of Bogatepe Village and its surroundings.

Boğatepe köyünün bulunduğu konum, büyük ölçüde Pliyosen'de Allahüekber Dağları'nın volkanik etkinliği sırasında birikmiş piroklastik kayaçların yayılış gösterdiği bir alana karşılık gelir. Yaygın olan volkanizma faaliyeti, eski yapı hatlarını örtmek suretiyle yeni bir relief düzeni ortaya çıkarmıştır. Bununla birlikte genellikle kolay aşınan türde malzeme veren bu alana Kura Irmağı'nın kolları sokularak kısmen boşaltmış bulunmaktadır. Kura'nın kolları Boğatepe Köyü'nün batısında yükselen tepelik alandaki volkanik örtü tabakalarını kısmen aşındırmış olduğundan, eski temele ait araziler, sıyrılmış yüzeylerin altından ortaya çıkmış durumdadır. Bu nedenle belirmiş mostralar, bu alanın en yaşlı arazisinin Paleozoik metamorfitlerinden oluştuğunu (şist, kuvarsit ve mermerler) göstermektedir. Aynı konumda yer Üst Jura-Kretase yaşlı neritik kireçtaşları ile Üst Miyosen-Pliyosen yaşlı dasit ve bazaltlar da yayılış göstermektedir (Şekil 3).

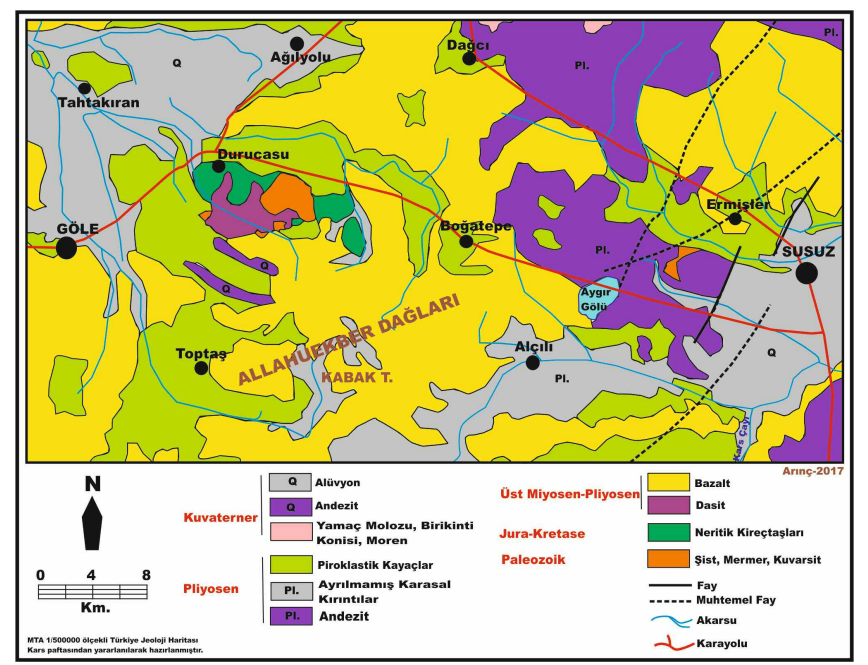

Şekil 3. Boğatepe Köyü ve çevresinin jeoloji haritası.

Figure 3. Geological map of Bogatepe Village and its surroundings.

Ardahan-Kars Yöresi, Oligosen'de kara ortamına geçmiş ve Güney Anadolu'da Alt Miyosen denizel transgresyonunun gerçekleştiği sırada da yükselmeye başlamışt. Yükselen plato, Oli- 
gosen ve sonrasında çoğunlukla düşey yönlü tektonik hareketlere maruz kalmış ve bu alçalma sırasında yer yer depresyonlar oluşmuş ve içleri molas çökelleriyle dolmuştur. Ancak ArdahanKars Yöresi, diğer havzalardan farklı olarak oldukça az tortul malzeme içeriğine sahiptir. Eski molas depolarının üzerine gelen volkanitlerin kalınlığı ise yaklaşık 500-1000 m. arasında değişir.

Yörenin büyük bir kısmını kaplayan lâvlar, daha çok eksojen volkanik domlar ve yarık-çatlak sistemlerinden kaynaklanmıştır. Lâv yayılması, Üst Miyosen'de başlamış ve Kuvaterner'e kadar lâv ve piroklastik maddeler birlikte çıkmıştır. Pleistosen'de ise sadece lâv çıkışı gerçekleşmiştir. Ardahan-Kars Yöresinde ortaya çıkan volkanizma etkinliğiyle ilgili farklı görüşler ortaya çıkmış bulunmaktadır (Tokel, 1984). Bununla birlikte alan ile ilgilenen araştırmacıların çoğu, Orta Miyosen'den beri devam eden sıkışma nedeniyle Doğu Anadolu'nun altında kalınlaşan yer kabuğunun kısmî ergimesi sonucu volkanizmanın başladığı görüşündedirler (Şaroğlu ve Güner, 1981; Savcı, 1980).

Boğatepe köyünün kuzeybatısında yer alan 150 km² yüzölçümünde olan Göle Ovası, 2000 m. yüksekliğinde olup tabanı Kuvaterner alüvyonlarıyla kaplıdır. Kura Irmağı'nın bu depresyonu drene etmesine karşılık, yarılma veya parçalanma derecesi düşüktür. Kura, Göle ve sıkça yatak değiştirdiğini gösteren kopuk mendereslere sahip Ardahan ovalarında yüzlek akarken, doğuya doğru yatağını derinleştirmiş ve araziyi daha fazla parçalamıştır. Göle Ovası Kuvaterner başlarına kadar lagüner ortamdayken, kuzeyden sokulan Kuruçay ile Kura havzasına bağlanmıştir. Yüksekliği 2000 m'yi aşan bu ovanın tabanında, hidromorfik alüvyal topraklar oluşmuştur. Bu nedenle doğal çayırlar ve bataklıklarla kaplıdır.

Ardahan-Kars Yöresi, ülkemizin en şiddetli ve uzun kışlara sahip olan kesimini oluşturur. Yıllık ortalama sıcaklıklar, Türkiye'nin başka bir yerinde görülemeyecek kadar düşüktür (Kars $4.8^{\circ} \mathrm{C}$, Ardahan $3.8^{\circ} \mathrm{C}$ ). Yörede yıl, soğuk ve orta sıcaklıkta olmak üzere hemen hemen eşit süreli iki dönemden oluşur. Üç kış ayı ve Mart ayında, aylık ortalama sıcaklıklar -2.1 ila $-11.2^{\circ} \mathrm{C}$ arasında değişir. Pek çok yıl $-30^{\circ} \mathrm{C}^{\prime}$ yi aşan sıcaklıklar, bu yöre için normal iklim olaylarından sayılır. Aylık sıcaklık ortalaması sadece Temmuz ve Ağustos aylarında $15^{\circ} \mathrm{C}$ 'nin üzerine yükselebilir. Sıcaklık amplitudu: Kars'ta $27.9^{\circ} \mathrm{C}$ ve Ardahan'da $27.5^{\circ} \mathrm{C}$ olarak hesaplanmış olup, bu değerler yörede yüksek bir karasalıı ortamının olduğunu göstermektedir. Bu nedenle hayat ve ekonomik faaliyetleri güçleştiren düşük sıcaklık şartları söz konusudur (Tablo 1, Şekil 4).

Boğatepe köyü ve yakın çevresinde yıllık toplam yağış tutarı 500 mm'nin üzerindedir (Kars 502.2 mm, Göle 620 mm, Sarıkamış $581.5 \mathrm{~mm}$, Ardahan $556.6 \mathrm{~mm}$, Posof $612 \mathrm{~mm}$ ). Yörede az yağışlı kışlar yaşanır (\%11-13 kadar). Kış mevsiminde kar örtüsü kalınlığı pek fazla değildir. Fakat bazı istisnai yıllarda yoğun günlük kar yağışı görülebilir ve $120 \mathrm{~cm}$.yi aşabilir, hatta toplam kar kalınlığı 2 m'ye ulaşabilir. Bununla birlikte yöreye düşen yağışların en büyük bölümü, ilkbahar sonunda ve yaz mevsiminde kaydedilir (Tablo 2, Şekil 5). Bu durum, kış mevsiminde Güneydoğu Toroslar ve Toroslar üzerine kadar ilerlemiş Hazar havzası ve Sibirya kökenli yüksek basınç kütlesinin, kıştan yaza geçerken menşe sahasına geri dönme çabası sırasında Ardahan-Kars Platosu üzerinde cepheler oluşturarak yaz yağışlarına neden olması ile dikey yönlü konveksiyonal hava hareketlerinin yağış miktarını artırmasıyla ilgilidir. Dolayısıyla bu alanda karasal bir iklimin karakteristik özelliklerinin belirdiği söylenebilir.

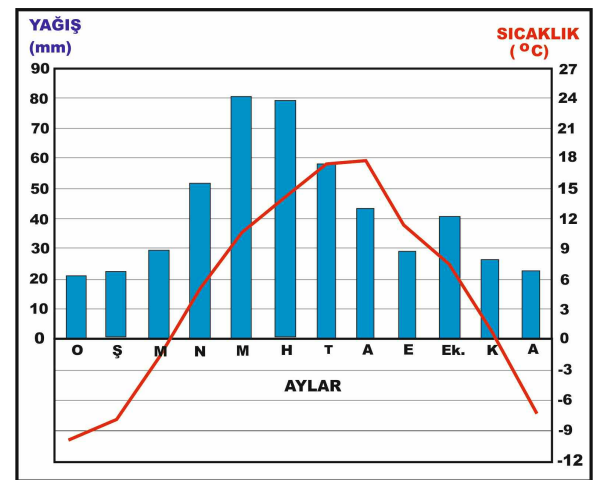

Şekil 4. Kars il merkezi'nde aylık ortalama yağış ve sıcaklı̆̆ın dağılım grafiği. Figure 4. Chart of temperature and precipitation changes by months in Kars province centre.

Tablo 2. Ardahan-Kars yöresinde yağışın mevsimlik dağılımı (1929-2016). Table 2. Seasonal distribution of precipitation in Ardahan-Kars Region (19292016).

\begin{tabular}{|c|c|c|c|c|c|c|c|c|c|}
\hline \multirow[t]{2}{*}{ ISTASYON } & \multicolumn{2}{|c|}{ ILKBAHAR } & \multicolumn{2}{|c|}{ YAZ } & \multicolumn{2}{|c|}{ SONBAHAR } & \multicolumn{2}{|c|}{ KIS } & YILUIK \\
\hline & $\mathrm{mm}$. & $\%$ & $\mathrm{~mm}$. & $\%$ & $\mathrm{~mm}$. & $\%$ & $\mathrm{~mm}$. & $\%$ & $\mathrm{~mm}$ \\
\hline Ardahan & 165.3 & 29.7 & 227.5 & 40.9 & 101.1 & 18.2 & 62.7 & 11.2 & 556.6 \\
\hline Kars & 161.8 & 32.2 & 178.6 & 35.6 & 95.9 & 10.1 & 65.9 & 13.1 & 502.2 \\
\hline
\end{tabular}

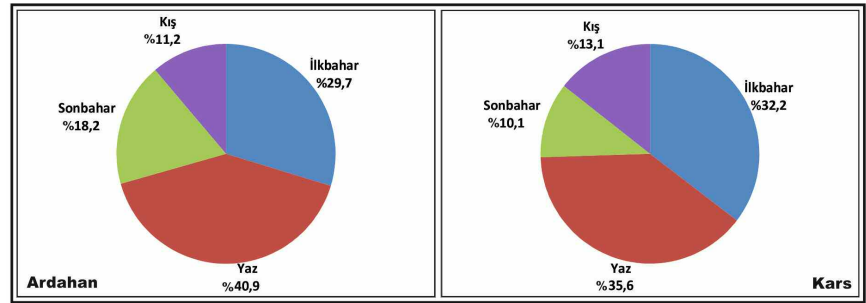

Şekil 5. Ardahan-Kars yöresinin yağış rejimi grafikleri.

Figure 5. Precipitations regime graphics of Ardahan-Kars region.

Tablo 1. Kars ve Ardahan il merkezlerinde ölçülen uzun süreli bazı iklim değerleri (1929-2016).

Tablo 1. Some long-term climate values measured in Kars and Ardahan provincal centers (1929-2016).

\begin{tabular}{|c|c|c|c|c|c|c|c|c|c|c|c|c|c|c|}
\hline VERI TURUं & ISTASYON & 0 & $S$ & $M$ & $\mathbf{N}$ & $\mathbf{M}$ & H & $\mathbf{T}$ & $\mathbf{A}$ & E & Ek. & $\mathbf{K}$ & A & YІLІК \\
\hline \multirow{2}{*}{ Ynlik Ort. Sicak: (E) } & Kars & -10.3 & -8.6 & -2.1 & 5.5 & 10.2 & 13.9 & 17.5 & 17.6 & 13.4 & 7.3 & 0.3 & -6.6 & 4.8 \\
\hline & Ardahan & -11.2 & -9.9 & -3.4 & 4.6 & 9.5 & 13.0 & 16.3 & 16.3 & 12.3 & 6.6 & -0.2 & -7.7 & 3.8 \\
\hline Ekstrem Yüksek Sicakliklar & Kars & 8.4 & 12.0 & 18.8 & 25.0 & 27.0 & 31.4 & 35.4 & 35.4 & 32.6 & 26.8 & 21.9 & 13.2 & 35.4 \\
\hline \multirow[t]{2}{*}{ Ekstrem Düşük Sicakliklar } & Kars & -36.7 & -37.0 & -31.5 & -22.6 & -7.0 & -4.0 & 0.1 & -1.9 & -4.4 & -17.5 & -30.0 & -35.0 & -37.0 \\
\hline & Ardahan & -39.8 & -38.7 & -33.2 & -22.2 & -8.5 & -4.5 & -2.2 & -2.8 & -5.8 & -15.0 & -28.9 & -36.3 & -39.8 \\
\hline \multirow[t]{2}{*}{ Aylik Yağis (mm) } & Kars & 21.2 & 22.4 & 29.6 & 51.7 & 80.5 & 77.3 & 57.9 & 43.4 & 28.9 & 40.8 & 26.2 & 22.3 & 502.2 \\
\hline & Ardahan & 19.2 & 20.8 & 30.9 & 52.3 & 82.1 & 94.5 & 70.3 & 62.7 & 35.2 & 37.0 & 28.9 & 22.7 & 556.6 \\
\hline \multirow[t]{2}{*}{ Ort. Yağıșl Gün Sayısı } & Kars & 10.6 & 10.4 & 11.5 & 13.6 & 18.2 & 14.8 & 10.6 & 8.7 & 7.1 & 9.7 & 8.7 & 10.3 & 134.2 \\
\hline & Ardahan & 9.5 & 9.8 & 11.5 & 13.8 & 17.0 & 15.5 & 11.4 & 10.9 & 7.7 & 9.6 & 9.0 & 9.7 & 135.4 \\
\hline \multirow[t]{2}{*}{ Aylik Ort. Basing (mb) } & Kars & 825.6 & 815.9 & 819.5 & 818.3 & 821.6 & 820.5 & 821.3 & 821.5 & 825.8 & 825.6 & 823.4 & 819.4 & 821.5 \\
\hline & Ardahan & - & - & - & - & - & - & - & - & - & - & - & - & - \\
\hline
\end{tabular}


Kurak mevsimi bulunmayan bir yağış rejimi ve yaz yağışlarının yüksekliği nedeniyle, Boğatepe köyü ve çevresi çayır ve mera alanlarıyla kaplıdır. İnceleme alanının kuzeydoğusunda yükselen Kısır Dağı'nda ve yakın çevresinde yapılan bir botanik araştırmasına göre; 60 bitki familyası, 266 cins ve bunlara bağlı 415 tür, 119 alt tür ve 43 varyete tespit edilmiştir. Alanda İran-Turan ve Avrupa-Sibirya (özellikle Öksin sektörüne dâhil türler fazladır) flora bölgelerine ait otsu türler ağırlıklı orandadır. Yöre vejetasyonundaki endemizm oranı ise $\% 5,4$ olarak belirlenmiştir (Ocakverdi, 2001).

Boğatepe köyü ve çevresinin çeşitli jeolojik zamanlara ait yaş ve litolojiye sahip arazilerden oluşması, bitki besini açısından zengin toprak horizonlarının belirmesine yol açmıştır. Bu durum yörede çok sayıda endemik bitkinin yetişmesini mümkün kılmıştır. Bitki çeşitliliği buradan beslenen hayvanlardan elde edilen sütlerinin aromatik özelliklerini değiştirmekte ve beğenilen peynir türlerinin üretilmesini kolaylaştırmaktadır (Güneş vd., 2011).

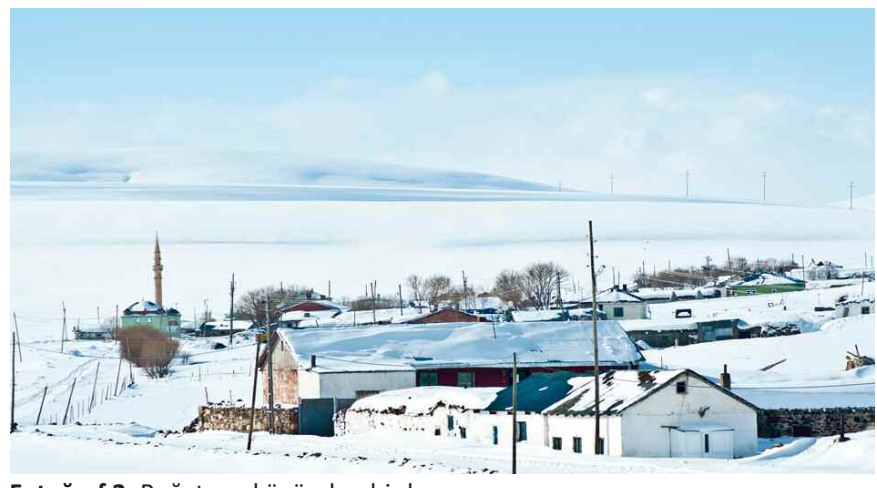

Fotoğraf 2. Boğatepe köyünden bir kış manzarası.

Photo 2. A winter view from the village of Bogatepe.

\subsection{Boğatepe Köyü ve Çevresinin Beşeri Coğrafya Özellikleri}

Boğatepe bir köy yerleşmesi olsa da yerleşme tarihi Türk-Rus mücadelesinin ve ortak tarihinin yansımalarını içeren özelliktedir. Bu yöreyi anlayabilmek için geçmişte oluşan şartları bilmek, yaşayan toplumların özellikleri ve faaliyetlerini incelemek gerekir. Bunlar arasında iki toplumdan özellikle bahsetmek gerekir. Ortodoks mezhebini yeniden düzenleyen 1660 yılındaki değişiklikleri kabul etmemeleri ve savaşmayı reddeden barışçıl bir Dünya görüşüne sahip olmaları nedeniyle Rus halkı tarafindan dışlanmış olan Ukraynalı Don Kazaklarından olan Doukhoborlar ve Beyaz Rus kökenli Malakanlar, 1839 yılından itibaren Çarlık topraklarının dışına atılmış toplumlar olarak tanınıyordu (Süvari, 2013). İlk olarak Dinyeper nehrinin Karadeniz'e yakın topraklarına, sonra da Transkafkasya'ya (Kafkasya ardı olarak bilinen Erivan, Tiflis ve Gence civarına) sürgün edilen bu iki toplumun, 1877-1878 Osmanlı-Rus Savaşı sonrasında Rusların eline geçen Ardahan-Kars yöresine de yerleştirildikleri bilinmektedir (Marshall, 2001). Belirtilen yıllarda Doukhoborlar ve Malakanların Kafkasya bölgesindeki nüfusu 50000 civarındaydı. Ardahan-Kars Yöresine getirilip yerleştirilenlerin sayısı ise 9500 kadardı.

Aslında Ruslar Ardahan-Kars Yöresine bunlar dışında da pek çok topluluğu yerleştirmiş ve kolonizasyon faaliyetlerine girişmişlerdi. Rus işgal döneminde toprak mülkiyeti yok sayılmış ve Ardahan-Kars Yöresinin Türk kimliğini yok etmek amacıyla Anadolu'nun çeşitli yörelerinden Süryani (Asurî), Rum, Ermeni ve Yezidi gibi unsurlar ve ağırlıklı olarak Kafkasya'dan göç etti- rilen Ukrayna, Osetin (Alan), Malakan, Doukhobor, Khakol, PoIonez, Nemiş (Alman) ve Estonya kökenli unsurlar yerleştirilmişti (Kırzıoğlu, 1953).

Doukhoborlar ve Malakanlar, kadın liderleri Lukeriya Kalmikova önderliğinde, Kafkasya'nın çeşitli yörelerinde komünal bir toplum yapısı oluşturmuşlardı. Sürgün yıllarında kollektif çalışmayı, birlikte üretmeyi, birlikte organize olmayı ve birlikte kazanmayı öğrendiler. Ardahan-Kars Yöresine gelen Doukhoborlar; Akyaka ilçesine bağlı Şahnalar, Karahan, Kuyucuk ve Susuz ilçesine bağlı Porsuklu köylerini kurdular. Malakanların ise 35 adet köy yerleşmesi kurdukları bilinmektedir (Arpaçay: Yalınçayır ve Atçılar, Kars: Büyükboğatepe, Küçükboğatepe, Çakmak, Çalkavur vb), (Süvari, 2013).

İşgal yıllarında Malakanlar için kurulan Zavot köylerinin Gravyer peyniri üretimi için elverişli olduğu anlaşılınca 1880 yılından itibaren ilk önce adı geçen köylerde sonra da Kars ilinin çeşitli yörelerinde Gravyer peyniri tesisleri oluşturulmaya başlandı. Hayata dair pek çok bilgiyle donanımlı olan Malakanlar geldikleri bölgelerde Gravyer peyniri üretimine aşina durumdaydılar. Bu nedenle Anadolu'ya getirilmiş her iki toplum; arıcılık, süt ürünleri işletmeciliği, büyükbaş hayvancılık ve at yetiştiriciliği konularında önemli başarılar elde ettiler. Özellikle yardımsever olan Malakanlar, ilkel metotlarla tarımsal faaliyetlerini sürdüren Ardahan-Kars Yöresi yerli halkına peynir üretimi, değirmencilik, bahçe ziraat, arıcılık ve hayvancılık gibi pek çok ekonomik faaliyet alanına bilgi sağlamak suretiyle katkı sağlamışlardı. Rus ordusunun ağır yük taşımada ve top arabalarını çekmede kullandıkları Wladimir atları, Zavot ırkı sığırlar, sabun üretimi ve yeni tarım ekipmanları yöre halkının günlük hayatına giren başlıca değişikliklerdi. Ardahan-Kars Yöresi halkını patates, ayçiçeği ve lahana gibi belli başlı ürünlerle ilk kez onlar tanıştırmışt. Dere boylarında kurdukları değirmenler civar köylüler için de çalışır, tahılların öğütülmesini ve az da olsa elektrik üretilmesini sağlardı. Malakanlar, geldikleri coğrafyanın konut kültürü örneklerini de bu yöreye taşıyarak, coğrafi renkliliği artırmışlardı (Akça vd., 2017), (Fotoğraf 3).

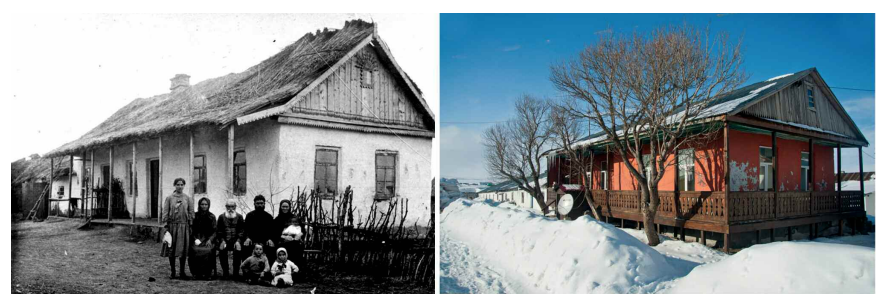

Fotoğraf 3. Boğatepe Köyü'nde XIX. yüzyılın başlarında yaşamış bir Malakan ailesi ve günümüze intikal etmiş bir Malakan konutu.

Photo 3. A Malakan family who lived in the village of Bogatepe, until beginning of the nineteenth century and a house of Malakan that can be reached recent time.

Malakanlar elde ettikleri ürünleri 1880 yıllarından sonra demiryolu ile Moskova'ya kadar ulaştirarak toplumlarının refah düzeyini yükselttiler. Fakat 1895 yılına gelindiğinde bu toplumları silahaltına almak isteyen Çarlık Rusya'sının talebini geri çevirmiş ve ellerinde bulunan savunma silahlarını imha etmişlerdi. Örgütlü başkaldırı üzerine Rus ordu birliklerinin şiddetiyle karşılaşttlar ve özellikle Kafkasya bölgesinde yaşayanlar ünlü yazar Lev Tolstoy ve yardım kuruluşlarının temin ettiği gemilerle Batum limanından başta $A B D$ ve Kanada olmak üzere Dünyanın çeşitli yerlerine göç ettiler (Semyenov, 2001). O tarihte denizaşırı göçe katılmayanların kısmen Ardahan-Kars Yöresine yerleş- 
tiği bilinmektedir.

Genellikle yol ve vadi boyu yerleşmeleri oluşturan Malakanlar tarafindan kurulan köylerden biri olan Büyükzavot, işgal yıllarda inşa edilen ve Rusya'dan Tiflis'e oradan da Sarıkamış'a kadar uzanan atlı tramvay hattının güzergâhı üzerindeydi ve atların dinlendirildiği bir ara istasyon özelliğindeydi. Bu toplum, genellikle tek veya iki katlı inşa edilen karkas veya bağdadi tipte Malakan evlerini inşa ettikleri gibi, Büyükzavot köyünün sert iklim şartlarına karşı ürünlerini ve hayvanlarını korumak amacıyla, yöreye özgü yarı beline kadar toprağa gömülü taş konut tarzını kendi geleneklerine göre uyarlayarak, özel bir konut alanı oluşturmuş bulunuyorlardı. Özellikle toprak örtülü çatıların, ahşap çatkılar üzerine taş döşenerek oluşturulmaları nedeniyle binaların Gravyer peynirinin üretim aşamaları için gerekli sıcaklık ve nem koşullarını karşılayabilecek ve yararlı bakteri faaliyetlerini kolaylaştırıcı özellikler kazandığı dikkati çekiyor. Yöre halkı bu konut tipini, soluyan binalar olarak nitelendirmektedir (Fotoğraf 4).

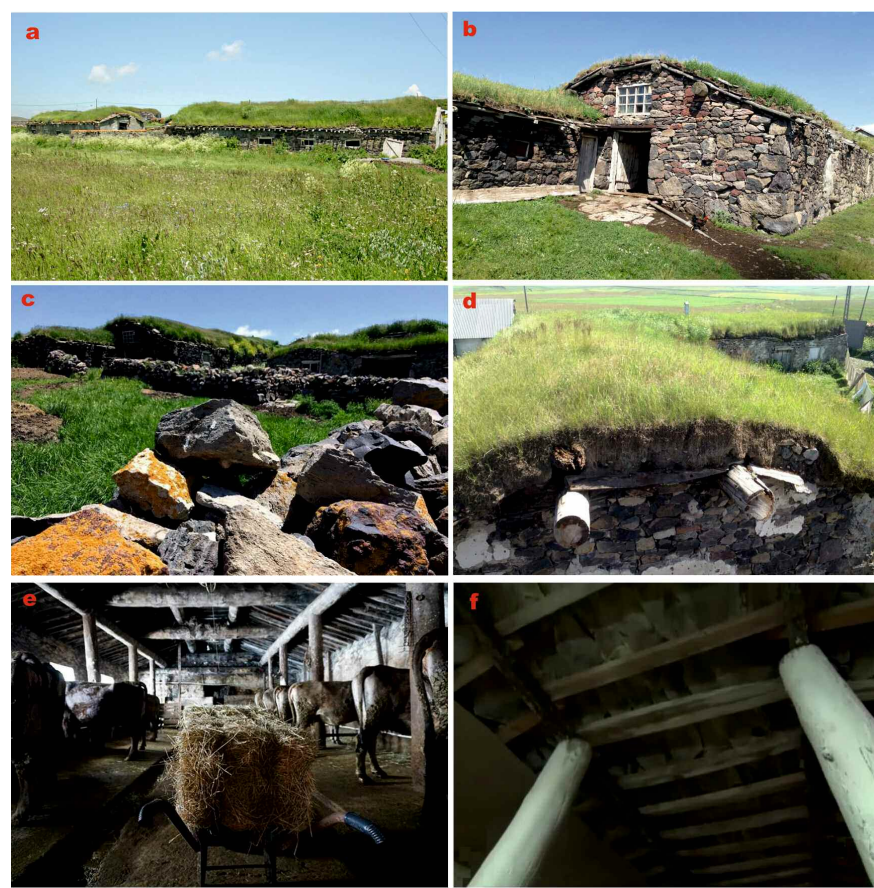

Fotoğraf 4. Boğatepe Köyü'nün çoğunlukla ahır ve depo olarak kullanılan toprağa gömülü geleneksel konut tipleri [a) Genel görünüm, b)Üst kat oturma mekânı, alt katı ahır veya depo olarak kullanılan bir konut tipi, c) Doğayla bütünleşmiş bir konut, d) Taş döşeli ve toprak örtülü çatı tipi, e) Ahır tipi, f) Ahşap hatıllar üzerinde taş döşeli tavan tipi].

Photo 4. Bogatepe Village's traditional housing types used as barn and warehouse in which buried in the ground (a) General view, b) Typical village house in which the upper floor is a living space, the lower floor used as a barn or a warehouse, c) A house integrated with nature, d) Roof type with stone pavement and covered with soil, e) Typical barn, f) Ceiling type with stone pavement on wooden beams].

İşgal yıllarında Rus yönetiminin, Ardahan-Kars Platosunu İsviçre Alplerine benzetmesi nedeniyle burada planlı bir hayvancılık geliştirme faaliyetlerine giriştiği bilinmektedir. Öncelikle bölgenin şartlarına uyum sağlayabilecek yeni bir büyükbaş hayvan ırkı oluşturmak amacındaydılar. Avrupa'dan getirdikleri yabancı ırk sığırlarla Doğu Anadolu'nun yerli ırk sığırlarını melezlemek suretiyle Zavot ırkı sığırları elde etmeyi başardılar. Ayrıca bu yıllarda Dünyanın pek az yerinde bilinen ve anavatanı İsviçre olan Gruyére peynirinin Ardahan-Kars Yöresi'nde de üretilebileceği öngörüsü üzerine İsviçreli bir peynir üreticisi olan David Moser,
Çar II. Nikolay tarafindan gerekli araştırmalar yapmak üzere Ardahan-Kars Yöresine gönderilmişti. David Moser, Büyükzavot köyünün Gravyer peyniri üretimi için elverişli olduğunu görünce burada ilk Gravyer peyniri üretim tesisini kurmuştu. Böylece yaklaşık 40 yıl boyunca Ardahan-Kars Yöresi'nde Zavot (Fabrika) adı verilen Gravyer peyniri imalathanelerinin sayısı 50'yi aşmış bulunuyordu (Fotoğraf 5).

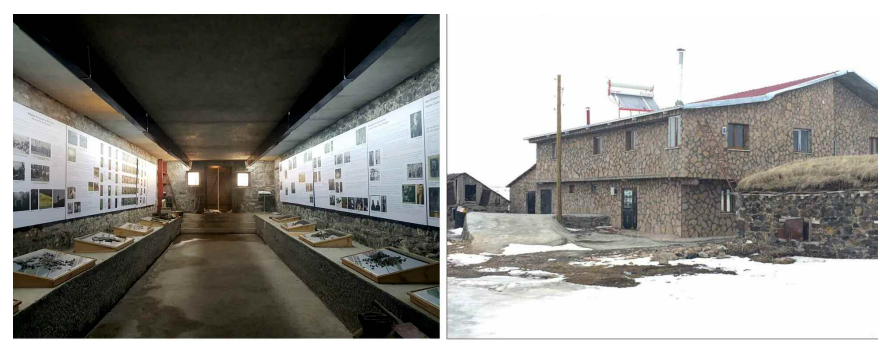

Fotoğraf 5. Solda Boğatepe köyünde David Moser tarafindan kurulmuş ilk gravyer peyniri üretim tesisi (burası günümüzde Eko Müze olarak düzenlenmiştir) ve Sağda Koçulu Peynirciliğe ait gravyer üretim tesisi.

Photo 5. On the left is the first gruyere cheese production facility established by David Moser in the village of Boğatepe (nowadays it is organized as Eco Museum) and on the right is a gruyere cheese production facility for Koçulu Company.

Aslında Gravyer peyniri İsviçreli peynir imalatçılarının girişimiyle Kafkasya'da 1850 yılında başlatılmış bulunuyordu. Ruslar Osmanlı Devletinin geri çekilmesinden istifade ederek ele geçirdikleri Kafkasya Bölgesi'ne 1850 yılından sonra Almanya ve İsviçre'den çok sayıda gravyer ustası ve ekipmanı getirtmişlerdi. Ayrıca başta Montofon olmak üzere bazı kültür ırkı sığırları da bu alana getirdiler. Bu nedenle Kafkasya halklarının bir kısmı uzmanlık düzeyinde bilgi ve görgü gerektiren Gravyer peynir üretimini yabancı ustalardan öğrenmiş bulunuyordu.

Malakanlar ve İsviçreli peynir imalatçıları, 1917 yılında Bolşevik ihtilalinin gerçekleşmesi ve Çarlık Rusyasının yıkılması üzerine kademeli olarak Ardahan-Kars Yöresinden ayrılmaya başladılar ve ağırlıklı olarak Tiflis'e yerleştiler. Oradan da Dünyanın çeşitli ülkelerine dağıldılar. Batum ve Kars, Ruslarla 3 Mart 1918 tarihinde yapılan Brest Litovsk anlaşmasıyla Osmanlı Devletine iade edilmişse de Mondoros Mütarekesi'nin hükümleri gereği Türk ordusu bu iki şehri boşaltarak geri çekilmişti. Bu süreçte Kars Ermenilere, Ardahan ve Posof da Gürcülere verilmişti. Bu süreçte yörede büyük bir insan kıyımı da gerçekleşmişti. Böylece Kars'ın nüfusu 1889 yılında 4000'e inmiş bulunuyordu. Hoffmeister ise Kars'ın 1911 yılı nüfusunu (askerî nüfus dâhil) 20000 olarak vermiştir (Erinç, 1953). Türkiye Büyük Millet Meclisi'nin oluşmasından sonra Kâzım Karabekir Paşa komutasındaki XV. Kolordu, 1920 yılında Kars'ı ve 1921 yılında da Ardahan, Posof ve Çıldır'ı düşman işgalinden kurtardı. Bu tarihten sonra yapılan Gümrü, Kars ve Moskova antlaşmalarıyla Türkiye Cumhuriyeti'nin sınırları kesinleşmiş oldu.

Ruslar tarafindan yöreye yerleştirilmiş kolonistler, Rus ordusunun ardından Türkiye topraklarını terk ettiler. Bununla birlikte yerel halkla iyi ilişkiler kuran ve zararsız olduklarına inanılan bazı Malakan ve Doukhobor aileleri, Türkiye'de kalmayı tercih etmişti ${ }^{1}$. Fakat göç mağduru Malakanların, 1921 yılında zorunlu askerliğe tabi tutulmak istenmeleri ve inançlarının toplum içi evliliği yasaklaması yüzünden evlenecek eş bulamamaları (kız-

${ }^{1}$ Ardahan-Kars yöresinde savaş karşıtığını koruyan Malakanlar, domuz eti yememeleri, gizli ibadeti benimsemeleri, kilise veya haç gibi dinsel simgeleri kullanmamaları sayesinde, yerel halka itici gelmemiş ve onlarla uyum içinde yaşamayı başarmışlardı. 
larını daha önce tanışıklıkları olan Terekeme Türkleri ile evlendirebilirken, bekâr erkekler evlenecek kız bulamama sorunu ile karşılaşmışt), bu yöredeki yaşayan bazı yerel grupların azınlıkların topraklarına göz dikmeleri ve Bolşevik ideolojisine yakın oldukları ithamlarının yapılması gibi nedenlerle 1962 yılına kadar SSCB, ABD ve Kanada gibi ülkelere göç ettikleri bilinmektedir.

Malakanların göç ederek yöreden ayrılmaları sonucu oldukça tenhalaşan Boğatepe köyü, 1936 yılında yeniden ülke dışından alınan göçlerle nüfuslanmaya başlamışt. Çünkü Sovyetler Birliği döneminde komünizm ideolojisi altında yaşamak istemeyen çeşitli Türk boylarına mensup toplumlar, milli mücadelenin kazanılmasından sonra, gruplar halinde ülkeye gelip yerleşmeye başlamışlardı. Özellikle Özbekistan, Kazakistan, Dağıstan ve Don-Volga boylarından göç eden bazı Kıpçak, Kuman, Komuk, Karapapak (Terekeme) ve Karakalpak boyları, Ardahan-Kars Yöresine gelmiş, bunlardan bir kısmı da Zavot köylerine yerleştirilmişti (Kemaloğlu, 2012). Böylece Büyükzavot köyü yeniden nüfuslanmaya başlamış ve nüfus miktarı 1940 yılında 360’a yükselmiş bulunmaktaydı. Köye yerleşenler, eski gravyer atölyelerinde hazır buldukları ekipmanlarla Gravyer peyniri üretmeye başladılar. Yaklaşık çeyrek yüzyıl boyunca Boğatepe köyü nüfusunu artırmış ve hayvancılık ekonomisinin gelişmesi ve başta gravyer olmak üzere sayısı 32'iyi bulan peynir çeşidi üretimi nedeniyle ortalamanın üzerinde gelir sağlayarak, göç olgusuna karşı direnmeyi başarmışt. Nitekim köyün 1965 sayımındaki nüfusu 727 olup, 25 yılda nüfusunu ikiye katlayan bir süreç yaşanmışt (Tablo 3, Şekil 6).

Tablo 3. Ardahan-Kars yöresinde yağışın mevsimlik dağılımı (1929-2016). Table 3. Seasonal distribution of precipitation in Ardahan-Kars Region (19292016).

\begin{tabular}{|l|c|c|c|c|c|c|}
\hline Sayım Dönemleri & Erkek & $\%$ Kadin & $\%$ si & Toplam & $\begin{array}{l}\text { Nüfusun Yollik } \\
\text { Dešisim Orani (\%) }\end{array}$ \\
\hline 1940 & 176 & 48.8 & 184 & 51.2 & 360 & - \\
\hline 1955 & 317 & 55.1 & 258 & 44.9 & 575 & 4.0 \\
\hline 1960 & 331 & 53.8 & 284 & 46.2 & 615 & 7.0 \\
\hline 1965 & 415 & 57.0 & 312 & 43.0 & 727 & 3.6 \\
\hline 1970 & 318 & 52.9 & 283 & 47.1 & 601 & -3.5 \\
\hline 1975 & 366 & 55.9 & 288 & 44.1 & 654 & 1.8 \\
\hline 1980 & 246 & 54.4 & 206 & 45.6 & 452 & -6.2 \\
\hline 1985 & 249 & 54.1 & 211 & 45.9 & 460 & 0.4 \\
\hline 1990 & 213 & 53.7 & 184 & 46.3 & 397 & -2.8 \\
\hline 2000 & 134 & 53.4 & 117 & 46.6 & 251 & -3.7 \\
\hline 2010 & 120 & 53.8 & 104 & 46.2 & 224 & -1.1 \\
\hline 2015 & 158 & 62.9 & 93 & 37.1 & 251 & 2.4 \\
\hline $1940-2015$ Ortalamasi & - & - & - & - & - & -0.4 \\
\hline
\end{tabular}

Kaynak: DíE Genel Nüfus İstatistikleri ve TÜiK ADNKS verileri.

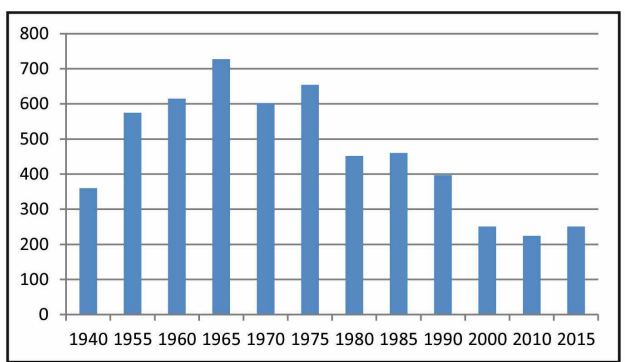

Şekil 6. Boğatepe Köyü’nün sayım ve tespit yıllarına göre nüfus grafiği.

Figure 6. Population graphics of Bogatepe Village according to census and determination years.

Bununla birlikte 1965 yılından sonra, Boğatepe köyünün hemen her yıl nüfus kaybettiği bir süreç ortaya çıkmıştr. Gerçekten de nüfus miktarı 2015 yılı sonu itibariyle 251'e inmiş bulunmaktadır. Nüfusun azalışı sorununun en önemli nedeni geçen süreçte hayvancılık ekonomisinin rantabl olmaktan çıkması olarak söylenebilir. Bugün 70 haneli olan Boğatepe'nin ortalama aile büyüklüğü 3.6 kişiye gerilemiş bulunmaktadır.
Genellikle orta yaş ve yaşlı nüfusun yıl boyu yaşadığı köyde, nüfus miktarı yaz aylarında neredeyse ikiye katlanmakta ve bu mevsimde artan iş yoğunluğunu karşılamak amacıyla dönen nüfus sayesinde, köyün nüfusu 500'ün üzerine çıkmaktadır. Bu arțş gravyer peyniri üretiminin gerektirdiği organizasyon ile kışlık ot biçme işleminin insan emeğine dayalı olarak sürdürülmesi nedeniyledir.

\subsection{Boğatepe Köyü’nün Ekonomik Özellikleri}

Boğatepe köyünde iklimin sınırlandırıcı etkisi yüzünden, ekmedikme şeklindeki tarım faaliyetlerinden yeterli gelir sağlanamadığı için, hayvancılık faaliyetleri en önemli geçim kaynağı durumundadır. Ortam ekolojisi nedeniyle yarıya kadar toprağa gömülmüş konutlar ve tamamen gömülü ürün depoları, geniş çayırlıklar, tezek ve ot yığınları ile sürüler halinde dolaşan kazlar, bu yörenin alışılmış manzaraları arasındadır. İnceleme alanında hayvancılık ekonomisini destekleyen meraların alanı yaklaşık 56000 dönümdür. Bu mera varlığından yararlanılarak beslenen büyükbaş hayvan sayısı 7000, süt veren sığır sayısı ise 4000 kadardır (Fotoğraf 6).

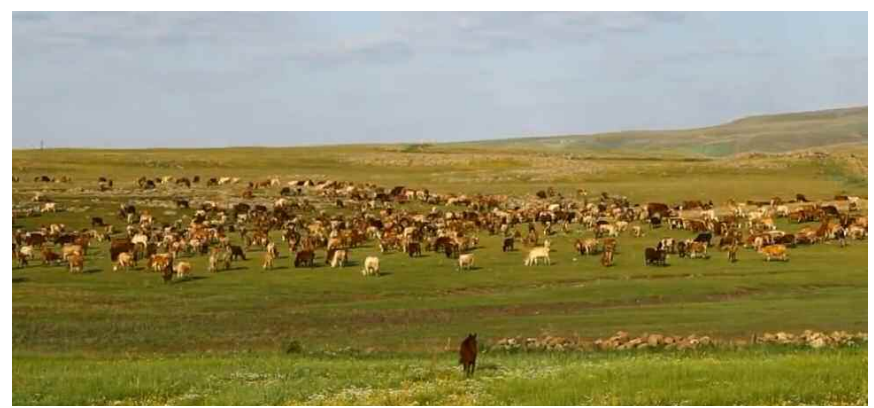

Fotoğraf 6. Boğatepe köyü merasında otlatilan sığırlar.

Photo 6. Cattle grazing in the pasturage of Bogatepe village.

Ardahan-Kars Yöresinde beslenen ve sayısı yarım milyonu aşan büyükbaş hayvanların büyük bir kısmı kültür ırklarından oluşur. Alanda rastlanan sığırlar Montofon, Simental, gibi yabancı ırklar ile Göle ve Zavot ırkı olarak tanınan yerli-melez ırklardır. Zavot ırkı, adını inceleme alanı olan Boğatepe'den alır. Bu ırkın Ukrayna step ırkı, İsviçre Esmeri ve Simental ırkı sığırlarla, Doğu Anadolu Kırmızısı'nın melezlenmesi sonucu ortaya çıktı̆ı bilinmektedir Zavot ırkı sığırlar, ortalama günlük 5-5.5 kg. ve yıllık 2000 kg süt verimine ulaşabilen iri cüsseli hayvanlardır. Bu ırkın hayvanlarının besiye alınmaları durumunda et verimleri, Doğu Anadolu Kırmızısına ve diğer yerli ırklara nazaran daha yüksektir. Özellikle faal olan mandıralar civarında bu ırkın yoğunluğu fazladır. Kanaatkâr bir tür olup yılın yarısını mera ve yaylalarda geçirirler. Bölgeye çok iyi adapte olmuş bu ırk, hastalıklara ve zor iklim şartlarına oldukça dayanıklıdır. Kötü barınma koşullarında ve engebeli arazide yetiştirilebilmektedir. Renkleri genellikle açık gridir ve nadiren açık sarı olanlarına da rastlanır (Fotoğraf 7), (Özşensoy, 2011).

Bir köy yerleşmesi için oldukça büyük bir varlık anlamına gelen büyük baş hayvan sayısının kısmen kasaplık et değeri olsa da hayvanlardan asıl yararlanma peynir üretimi konusundadır. Boğatepe köyünde zaman zaman üretilen peynir türü sayısı 32 kadardır (Gravyer, Kaşar, Malakan, Motal, Çeçil, Tulum, Beyazpeynir vb.). Bununla birlikte kaşar peyniri ve Gravyer peyniri dışında kalanların üretim miktarı önemsizdir. Son yıllarda bu köyün ekonomik faaliyetlerini çeşitlendirmek amacıyla yö- 
renin 650 türü aşan florasından yararlanma girişimleri başlatılmıştır. Genellikle girişimci ev kadınlarının öncülügünde tıbbî ve aromatik bitkilerin kurutulması, yağının damıtıması ve çeşitli kimyasallar elde edilmesi konusunda çalışmalar yapılmaktadır (Seçkin, 2016), (Fotoğraf 8). Ancak uzmanlık gerektiren bu faaliyet amatör düzeyde yapılabildiğinden, ilaç, şampuan, el, yüz ve vücut kremlerinin imalat konusunda üniversitelerin desteğine ihtiyaç duymaktadırlar. Boğatepe Çevre ve Yaşam Derneği öncülüğünde yürütülen bu çalışmalarla yörenin ekoturizm potansiyelinden de yararlanılmak istenmektedir. Zaman zaman yurt dışından bu köye gelen yabancı ziyaretçilerle diyaloglarını geliştirmek amacıyla yöre kadınları yabancı dil öğrenmektedirler (Eroğlu vd., 2015).

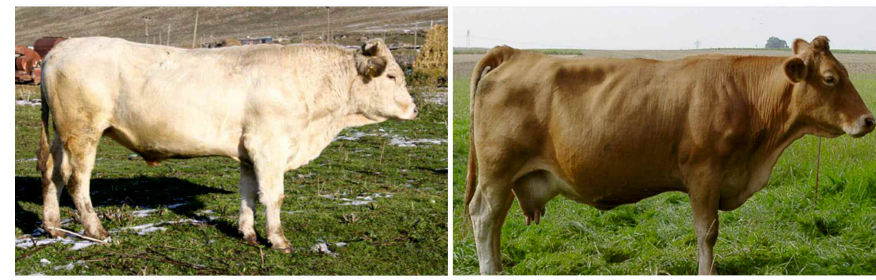

Fotoğraf 7. Ardahan-Kars Yöresinde beslenen iri cüsseli Zavot ırkı sığırlar. Photo 7. The large-bodied Zavot cattle fed in the Ardahan-Kars region.
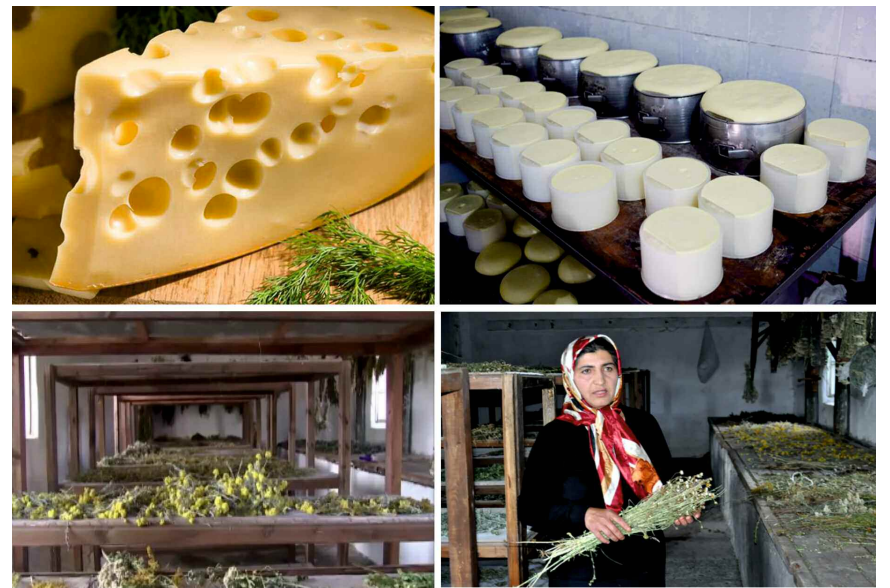

Fotoğraf 8. Boğatepe Gravyeri ve Kaşar peyniri ile bitki kurutma atölyesi.

Photo 8. On the left Gruyere cheese of Bogatepe, on the right cheddar cheese and at underside a plant drying workshop.

\subsubsection{Boğatepe Köyü'nde peynir üretimi}

Gravyer peyniri altı-yedi ayı bulan ve olgunlaşması için bir yıllık bir zaman dilimi gerektiren çok zahmetli bir üretim süreci sonunda elde edilebilen, besin değeri yüksek nadir peynir türlerinden biridir (Tablo 4). Bu peynir, üretim sürecinin çok özel ve uzun olması nedeniyle uyutulmuş probiyotik bakterilerin biriktiği bir ortam halindedir. Gerçekten de Slow Food Foundadtion for Biodiversity adlı kuruluşun araştırmalarına göre İsviçreli türdeşinin aksine Boğatepe Gravyeri'ne probiyotik bakteriler aşılanmamakta, bu bakteriler üretim ortamından doğal yollarla peynirin içine alınmaktadır². Bu nedenle yemek sonrası tüketildiğinde, faydalı bakteriler, uyanarak sindirim sistemi bozulmuş insanların bağırsak florasının yeniden oluşturmaktadır. Bu yönüyle gravyer, doğal bir ilaç anlamını da taşır.

Aslında bu peynir türü, XIII. yüzyıldan beri İsviçre'de Leman Gölü’nün kuzeydoğusundaki Gruyère kasabasında üretilmekte olduğundan, bu kasabanın adıyla tanınmaktadır. Bununla birlikte

${ }^{2}$ https://www.fondazioneslowfood.com/en/slow-foodpresidia/bog\%CC\%86atepe-gravyer/ gözeneksiz olan Gruyère gravyeri, Ardahan-Kars Yöresinde form değişikliğine uğrayarak gözenekli hale gelmiş bulunmaktadır. Bu değişiklikle birlikte Boğatepe Gravyeri veya Kars Gravyeri adını alan bu özel peynir türü, görünüm olarak İsviçre kökenli başka bir tür olan gözenekli Emmental peynirini andırsa bile tat ve üretim süreci bakımından farklılık gösterir (İsviçre Gruyère'si gözeneksiz ve tuzlu, Emmental ise gözenekli ve az tuzlu peynir türleridir).

Tablo 4. Bir porsiyon (100 gr.) Gravyer peynirinin besin değerleri. Table 4. Nutritional Values of a Portion of Gruyere Cheese (100 gr).

\begin{tabular}{|c|c|c|c|c|c|}
\hline Kalori & & & $413 \mathrm{kcal}$. & Protein & $30 \mathrm{gr}$. \\
\hline Yă̆ & & & $32 \mathrm{gr}$. & Kalsiyum & $\begin{array}{r}1.011 \\
\text { gr. }\end{array}$ \\
\hline Kollesterol & & & $110 \mathrm{mg}$. & A Vitamini & $948 \mathrm{IU}$ \\
\hline Sodyum & & & $336 \mathrm{mg}$. & D Vitamini & $24 \mathrm{IU}$ \\
\hline Potasyum & & & $81 \mathrm{mg}$. & B6 Vitamini & $0.1 \mu \mathrm{g}$ \\
\hline \multirow[t]{2}{*}{ Karbonhidrat } & Diyet Lifi & $0.0 \mathrm{gr}$. & \multirow[t]{2}{*}{$0.4 \mathrm{gr}$. } & B12 Vitamini & $1.6 \mu \mathrm{g}$ \\
\hline & Şeker & $0.4 \mathrm{gr}$. & & Magnezyum & $36 \mathrm{mg}$. \\
\hline Piridoksin & & & $0.1 \mathrm{mg}$. & Demir (Fe) & $0.2 \mathrm{mg}$. \\
\hline
\end{tabular}

Kaynak: Breakfast Dergisi. 2017. Sayı:6.

Boğatepe gravyerinin doğuşunun tarihsel bir süreçle ilgisi vardır. Kolonistlerin Türkiye'den ayrılmaya başladıkları sırada, bu yörenin mandıralarının çoğuna sahip olan David Moser, gravyer peyniri imalathanelerini Alman kolonist Alexander Kaiser'e satarak bölgeden ayrılınca, üretim süreçlerine Almanların peynir üretim metotları da katılmış bulunuyordu. Bu nedenle imalathanelerin el değiştirmesi, İsviçreli Gruyère peynirinin, Kars gravyerine dönüşümünün başlangıcı olarak kabul edilmektedir.

Gravyer peyniri üretimi çok zahmetli işbölümü gerektiren, emek yoğunluğu yüksek bir ekonomik etkinliktir. Bu nedenle Boğatepe köyünde sadece 2 imalathane bu peynir türünü üretebilmektedir (köyde faal olan 5 mandırada sadece kaşar peyniri imal etmektedir). Boğatepe Köyü halkının kurduğu bir kooperatif sayesinde, peynir üretimi konusunda önemli bir işbölümünü gerçekleştirmiş bulunmaktadırlar. Nitekim köy halkının bir bölümü peynir üretirken, diğer bölümü üretime süt sağlayacak hayvancılık faaliyetini sürdürmektedir. Örneğin yörenin en nitelikli firması olan Koçulu Peynircilik, halen 38 çiğ süt üreticisiyle ortaklık kurmuş durumdadır. Ayrıca civar köyler ve bunlara bağlı yaylalardan da zaman zaman süt alımı yapılmaktadır.

Gravyer peyniri üretimi için oldukça nitelikli bir süt üretimi gereklidir. Yörenin yükseltisi fazla olan meralarında Mayıs ayı ortalarında başlayan çiçeklenme, Ağustos ayı sonuna kadar sürdüğünden, belirtilen ortamdan beslenen hayvanların sütü gravyer için uygun yağ oranına sahip olmaktadır. Üretiminde kullanılacak sütün 1800 m'den yüksek kuşakta elde edilmesi, yağ oranının fazla yüksek olmaması ve sağım sonrasında asitlik derecesinin yükselmemesi için bir saati aşmayacak bir sürede toplanarak mayalanması gereklidir.

Gravyer peyniri üretim dönemi, bitkilerin çiçeklenme dönemine de karşılık gelen Mayıs ayında başlamakta ve Ağustos ayı sonuna kadar devam etmektedir. Yöredeki yaz sıcaklıklarının fazla yüksek olmaması nedeniyle zararlı bakteriler düşük oranda kalmakta bu da üretimi olumlu etkilemektedir. Gravyer imalathanesine getirilen sütler, yaklaşık 1 ton süt alabilen bakır, altın (bir kazanın imalatı sırasında yaklaşık 2.5 kg. altın kullanılmaktadır) ve gümüş alaşımlı büyük kazanlarda ısıtılmakta ve sıcaklık $35^{\circ} \mathrm{C}^{\prime}$ ye ulaştı̆ında doğal maya (Şirden maya) ile 
mayalanmaktadır (Fotoğraf 9a).

Mayalanmış peynir daha sonra harbi adı verilen telli araçlarla, pirinç tanesi büyüklüğüne gelene kadar parçalanır (Fotoğraf 9b). Bu işlemden sonra gravyer kazanı yeniden ısıtılmaya başlanarak karıştırma işlemi sürdürülür. Peynir taneleri eşit oranda ısınan bakır kazanın yüzeyine çarparak pişmeye başlar. Pişme işi 40-45 dakika kadar sürer. Ateşi kapadıktan sonra da kazanda bulunan peynir, kazanın sıcaklığından faydalanarak 10 dakika daha pişirilir.

Kendi suyu içinde pişen peynir, bohçalama işlemi için iki katlı bezin içine alınmaktadır. Sıkım sırasında peynirin içinde bulunan laktoz önemli ölçüde peynirden ayrılmaktadır. Bu nedenle kazanda kalan peynir suyunda prebiyotikler ve probiyotikler kaldığı için bu su, ekmek hamuru yapma ve turşu kurma gibi işlerde kullanılıyor. Bohçalanan peynir bir kaldırma mekanizmasıyla alınıp suyunun süzülmesi beklenmekte ve kalıplara konulmaktadır (Fotoğraf 9c,d,e). İlk bezleme aşamasından sonra Gravyer tekerleğinin ağırlığı 85 kg. kadardır. Presleme sırasında bez değiştirme işlemi 5-6 kez yapılır (Fotoğraf 9f). Bu işlem 200 kg'dan başlar ve 3,5 tona kadar yükseltilir. Bu nedenle gravyer kullanılan son bezi (bohçayı) ıslatamayacak kadar sudan arınmış hale gelir.

Presleme işleminden sonra 24 saat dinlendirilen gravyer, olgunlaşma deposuna aktarılmaktadır (Fotoğraf $9 \mathrm{~g}$ ). Müşahede odası adı da verilen bu depoda, gravyer 24 saat bekletilerek gözlemlenir. Şayet bu sürede herhangi bir üretim problemi gözükmüyorsa dış yüzeyi tuzlanır ve 24 saat daha bekletilir. Son işlem olarak gravyerin markası ve üretim tarihi üzerine yazılır. Ancak gravyerin üretimi bu işlemle bitmemiş olmaktadır.

İşlem görmüş gravyer, Kağızman veya Tuzluca tuzlalarından getirilen kaya tuzuyla hazırlanmış ve \%20 oranında yoğunlaştırılmış bir salamura havuzuna konulur. Bunun amacı presleme sonrasında peynirin içinde kalan az miktarda suyun, yoğunluk farkından dolayı, dışarıya atılması ve dış kabuğun daha sağlıklı
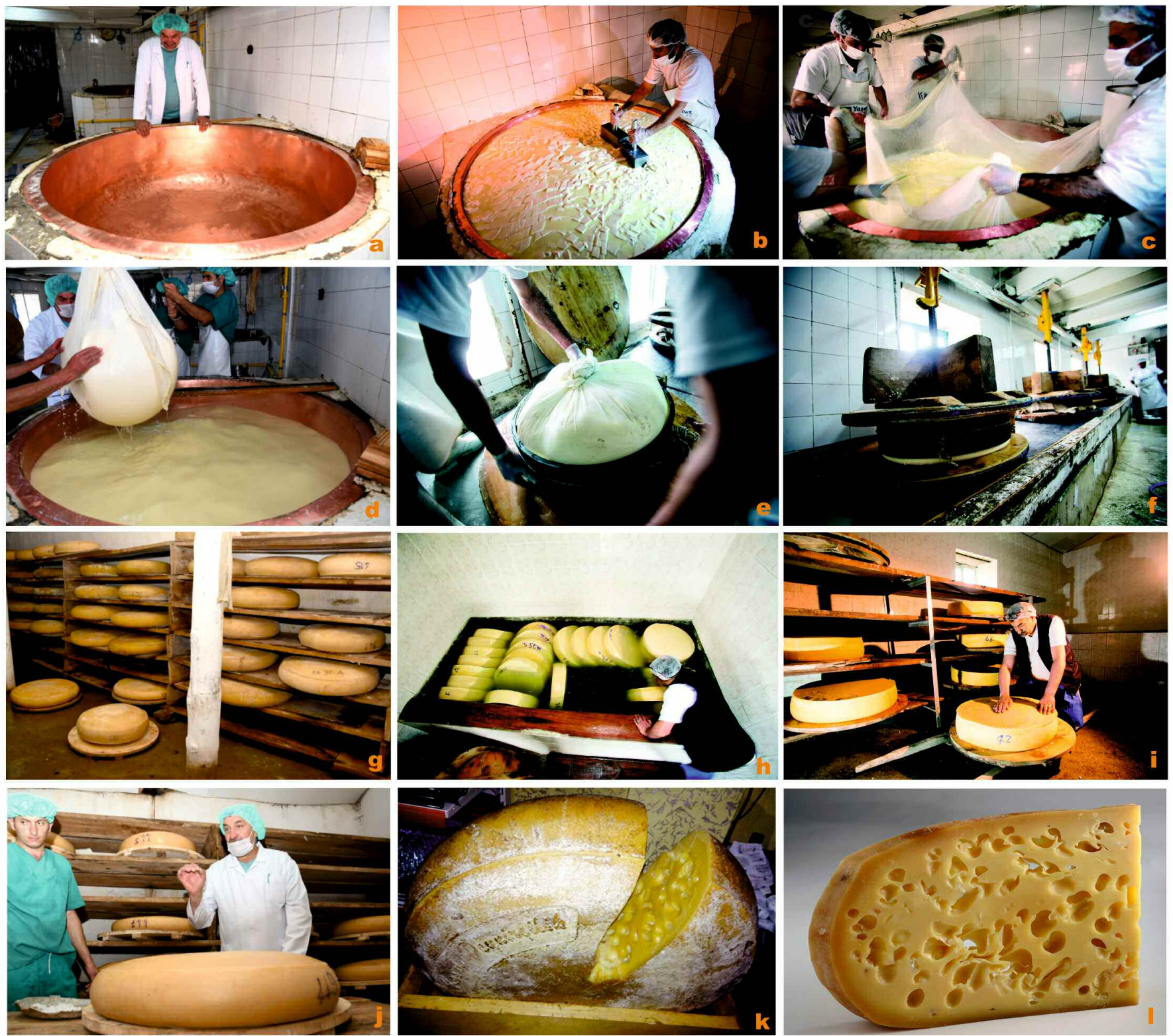

Fotoğraf 9. Boğatepe Köyü’nde Koçulu Peynirciliğe ait Gravyer Peyniri Üretim Tesisi ve Üretim Aşamaları [a) Altın, gümüş ve bakır bileşimli kazan, b)Mayalama ve parçalama aşaması, c)Torbalama, d)Süzme, e) Preslemeye hazırlık, f)Presleme, g)Dinlendirme, h)Tuzlu su havuzunda dinlendirme, i)Saunada fermantasyon aşaması, j) Soğuk odada dinlendirilmiş gravyer, k ve I) Olgunlaşmış ve satışa hazır hale gelmiş Gravyer peyniri].

Photo 9. Gruyere production facility and production stages of Koçulu Cheese in Bogatepe village [a]Boiler made of gold, silver and copper, b) Stage of brewing and shredding, c)The stage of bundling, d)Filtration stages, e)Preparing for press, f) Pressing stage, g)Mature stage, $h$ ) Relaxation phase in salt water pool, i)Fermentation phase at the sauna, j) Relaxation phase in cold room, $k$ and I) Ripe and ready for sale Gruyere cheese]. 
oluşmasıdır. Böylece 5-6 gün tuzlu suyun içinde kalan peynirin aroması da zenginleşir (Fotoğraf 9h).

Tuzlu su havuzundan alınan gravyer tekerlekleri sobayla ısıtılarak sıcaklığı $28-30^{\circ} \mathrm{C}$ arasında tutulan ve sauna adı verilen bir dinlenme odasına alınır. Bundaki amaç peynirde odacıkları oluşturacak faydalı bakteri faaliyetini başlatmaktır. Gravyer saunada 21 ile 30 gün arasında ahşap raflarda dinlendirilir. Bu süre içinde peynirler sıcaklık kaynağına doğru, her gün düzenli olarak kendi etraflarında döndürülürler. Her iki günde eşit şekilde havalanmaları için alt-üst edilirler. Peynirin ilk dört gün terlemesi nedeniyle çıkan terin tuzlu suyla silinmesi gerekir. Dört gün sonra peynirin yağı eşit şekilde dağılarak homojenize olur. Saunada gün geçtikçe peynir kabarmaya ve göbeklenmeye başlar. Bu sırada peynirin kalınlığı 20-25 cm'ye kadar ulaşır. Çünkü ısınma sürecinde probiyotik bakteriler canlanmış, çoğalmış ve laktozları parçalamaya başlamışlardır. Laktozların parçalanması sırasında çıkan $\mathrm{CO} 2$ gazı kabarcıklar oluşturur ve böylece Gravyerin içindeki odacıkların oluşması bu süreçle mümkün hale gelir (Fotoğraf 9i).

Sauna aşamasının sonunda gravyer peynirinin içindeki bakteriler yeterli sayıya ulaşırlar. Bu nedenle canlanmış bakterilerin yeniden uyutulmasını sağlamak amacıyla, gravyer tekerlekleri 90 ila 150 gün süreyle kalacakları sıcaklığı $12-13^{\circ} C^{\prime}$ ye sabitlenmiş soğuk odaya alınırlar (Fotoğraf 9g).

Yarısına kadar toprağa gömülü olan ve tavanı taş döşeli olan bu depoda Gravyer tekerlekleri ilk iki ay boyunca her 4 günde, ikinci 60 günde haftada bir ters yüz ediliyorlar. Gravyerin bu depoda bekletildiği ilk 30 gün boyunca her gün tuzlu suyla silinmesi en önemli işlemlerden biridir. Soluyan binalarda gravyer her geçen gün ağır ağır kurur, lezzetlenir ve olgunlaşır. Bu doğal yöntem sayesinde standartları yüksek modern üretim tesislerinde üretilenlerden farklı, doğayla uyumlu ve lezzetli bir peynir türü elde edilmiş olmaktadır. Gravyer peyniri kesilmeden, 0 $1^{\circ} \mathrm{C}$ arasındaki sıcaklık ortamında dört yıl saklanabilir. Ancak bekleme ortamının nem oranı \%75 civarında olmalıdır. Aksi takdirde peynir kurur ve çok sertleşir.

\subsubsection{Gravyer peynirinin pazarlanması}

Daha önce de ifade edildiği üzere kolonistlerin Ardahan-Kars yöresinde bulundukları yıllarda Gravyer peyniri üreten atölyelerin sayısı 50 civarındaydı. Bu sayı 1905 yılı kayıtlarına göre 33'e inmiş ve 1938 yılında da 21'e gerilemişti. İkinci Dünya Savaşı yıllarında gravyer imalathanesi sayısı 6’ya inmiş ve 2000 yılına gelindiğinde ise yörede sadece üretim yapan bir adet mandıra kalabilmişti. Bitme noktasına gelen bu faaliyetin unutularak ortadan kalkmasını, eğitimli bir gravyer ustası olan İlhan Koçulu'nun 2002 yılında köyüne dönerek gravyer üretimini yeniden başlatması önlemiştir. Ailesine ve çevresine öncülük eden bu girişimcinin yeni bir mandıra kurması ve geleneksel üretim biçimiyle birleştirmesi sonucu Boğatepe köyü halkı yeniden katma değeri yüksek bir tarımsal ürünü üretebilme şansını elde edebilmiştir. Halen Boğatepe köyünde gravyer peyniri üretimi yapan 2 imalathane ve 5 adet de kaşar peyniri üreten mandıra bulunmaktadır. Kars kentinde ise halen 49 mandıra bulunmakta ve bunlardan sadece ikisi (Uğurlu Süt ve Ser Süt) Gravyer peyniri imal etmektedirler.

Boğatepe köyünde laktasyon dönemi içinde günlük 18000 litre civarında süt elde edilebilmekte ve bunun 10000 litresi gravyer peyniri üretiminde kullanılmaktadır. Bir kilogram gravyer peynirinin üretilebilmesi için $17 \mathrm{~kg}$. süt kullanılmasının gerekli oluşu nedeniyle, Boğatepe köyünde günlük yarım tonu aşan bir gravyer peyniri üretimi söz konusudur. Tutulmuş bir istatistik olmamasına karşın, yaklaşık 100 günlük üretim süreci boyunca elde edilen Gravyer peyniri miktarının yaklaşık 50 ton kadar olduğu, Kars ili genelindeki toplam üretimin ise 170 tona ulaşt̆ğı tahmin edilmektedir (Topuk, 2014).

Üretilen Gravyer peynirinin en büyük alıcısı Karadeniz Bölgesi kıyı illeridir. Ayrıca son yıllarda bu peynir türünü tüketmeye alışık olan diplomatik misyonların yer aldığı İstanbul, Ankara ve İzmir gibi büyük kentler ile turistik talep nedeniyle Antalya ilinden de Gravyer peynirine alıcı çıkmaktadır. İhracata yönelik pazarlama ise henüz söz konusu değildir. Bu peynir türünün yüksek gelir düzeyine erişmiş, farklı tatlar arayan Ortadoğu ülkelerine pazarlanması mümkündür. Avrupa ülkelerinde ise Gravyer peynirini tüketmeye alışkın çok büyük bir nüfus kitlesi bulunmaktadır. Bununla birlikte Avrupa Birliği'ne dahil ülkeler, $X X$. yüzyılın ikinci yarısından itibaren hijyen kurallarına uygun olmadıkları gerekçesiyle Türkiye'den süt ve süt ürünleri alımı yapmamaktadır. Oysa Fransa ve İsviçre'nin bazı yörelerinde, gıda hijyen standartlarının göz ardı edildiği ve bu gibi yörelerin eko-biyolojik denge ve özellikleri gözetilerek istisnai uygulamalara gidildiği bilinmektedir. Ardahan-Kars Yöresinde üretilen Gravyer peynirinin boşluklarını oluşturan ve peyniri olgunlaştran bakteri florasının halen var olması, bu alanın ekolojik döngünün henüz bozulmadığını göstermektedir. Bu nedenle yörenin hijyen bakımından istisnai alanlar içine alınması, ihracat bakımından büyük önem taşımaktadır.

Türk halkının ise Gravyer peynirini tanımadı̆̆ı, faydalarını bilmediği ve bu yüzden de satın almadığı bilinmektedir. Aslında henüz dağıtım zincirinin oluşmaması nedeniyle, üretim-tüketim noktaları arasındaki soğuk zincirin kurulamaması, üretim aşamasındaki hataların veya satış noktalarındaki sağlıksız koşulların gravyer peynirinin tat ve aromasında bozulmalara yol açması ile tuz oranının yüksekliği Gravyer peynirine olan talebi düşüren diğer nedenler arasındadır. Bu nedenle pazarlama konusunda çok önemli sorunlar yaşanmakta ve yetkililerin bu konuda ilgisi beklenmektedir.

\section{Sonuç ve Öneriler}

Boğatepe köyünde az sayıdaki insanın çabasıyla sürdürülebilen Gravyer peyniri üretimi, katma değeri yüksek ekonomik faaliyetlerden biridir. Bir yönüyle bu üretim biçimi, tarım kesiminin girişimci ruhunu sembolize eder. Büyük kentlere göç ederek toplumsal sorunlara yol açan kırsal nüfusunu, geldikleri yerlerde tutma çabası içinde olan Türkiye'nin, bölgesel ve lokal öneme sahip bu üretim biçiminin kaybolmasını önleyici tedbirleri alması zorunludur. Gravyer peyniri üretimi büyük bir tarımsal organizasyon gerektirmektedir. Bu durum hem hayvan sayısının azalmasını önlemekte, hem de kırsal alana yeterli gelir sağlayabilmektedir.

Gravyer peyniri üretimi, yükseltisi 1800 m'nin üzerinde, nüfusu 500 civarında ve süt elde edilebilen sığır sayısı yeterli düzeyde olan (4000 baş civarında) her köy için yılda 2-2.5 milyon TL'lik gelir sağlayabilecek bir iktisadi faaliyettir. Ardahan-Kars Yöresinde bu şartları karşılayabilen en az 50 köy yerleşmesi bulunmaktadır. Cumhuriyet öncesi dönemde bu yörede yabancılar 
tarafindan yılda 2500 tonun üzerinde gravyer peynirinin üretilip pazarlandığı düşünüldüğünde, bugün söz konusu imkândan yararlanılamadığı gerçeğiyle karşılaşılır. Bu durumda yapılması gereken en önemli çaba Gravyer üretimini bilen ustaların eğitici olarak görevlendirilmeleri suretiyle uzmanlık gerektiren üretim biçiminin, yeniden kırsal kesimde yaygınlaştırılması olacaktır. Bu hedefin gerçekleşmesi için yöre halkına ekipman sağlama, depolama, soğuk zincir oluşturma ve pazarlama gibi konularda Devletin yardımcı olması ve öncü roller üstlenmesi gerekmektedir. Çünkü alanın eğitim düzeyi, girişimci gücü ve sermayesi, bu düzeni oluşturacak ve üretimi organize edebilecek yeterlikte değildir.

Diğer yandan üretim ortamı oluşturulabildiği takdirde, bu kez de elde edilen ürünün pazarlanması sorunu ortaya çıkacaktır. Gravyer peynirinin en kaliteli biçimde üretilebildiği konumlardan biri olan Boğatepe köyünün bile pazarlama sorunu yaşaması, benzer girişimler için cesaret kırıcıdır. Gerek kırsal alanda gerekse Kars kentinde peynir üreticilerinin arda arda iflas etmesi ve imalathanelerin kapanması gerek üretim sürecinde ve gerekse pazarlama konusunda önemli sorunlar yaşandığının belirtisidir.

Pazarlama sorunu Gravyer peynirinin insan sağlığı için taşıdığ önemin yeterli düzeyde topluma anlatılması ile çözülebilir. Bununla birlikte üretilen gravyerlerin Türk halkının ağız tadına uygun şekilde üretilmesi esas olmalıdır. Özellikle aşırı tuzlu olması ve son tüketiciye ulaşt̆ğında ortaya çıkan tat bozukluklarının giderilmesi gerekir. Kars Gravyerinin İsviçre kökenli Emmental peynirinin tuzluluk oranına getirilmesi bile müşteri kitlesini artırabilir. Bu konuda araştırma kuruluşlarının ve üniversitelerin bilimsel desteğine ihtiyaç vardır.

Bilhassa Kars Organize Sanayi Bölgesi'nde üretilen gravyer peynirlerinde ortaya çıkan tat bozukluğu giderilmesi gereken önemli bir sorundur. Bu türün üretiminde uzmanlaşmış kişilerden alınan bilgilere göre; üretim aşamalarında sıcaklık değerlerinin iyi ayarlanmaması veya üretim sürecini hızlandırma amacıyla yapılan proses değişiklikleri, tat bozukluğuna yol açan bakterilerin üremesine sebep olmaktadır (Topuk, 2014). Bu tip sorunların giderilmesi ise uzun zaman alabilmekte ve mali kayıpları artırmaktadır.

Geleneksel yöntemlerle organik olarak üretilen Ardahan-Kars Yöresi peynirlerinin yararlı bakteriyolojik koşulların korunabilmesi için bu alanın Kültürel Peyzaj Mirası olarak UNESCO Dünya Miras Listesi'ne alınması ile üniversiteler ve bölgesel kalkınma ajanslarının koruma konusunda kapsamlı çalışmalar yürütmesi gerekmektedir. Gerçekten de geleneksel mera hayvancılığının ve bu faaliyete dayalı ürünlerin giderek ortadan kalkması, sadece lezzetlerin kaybolması anlamını taşımamakta, insan sağıı̆ını bozucu etkiler yapması beklenmektedir.

Son zamanlarda bazı yayın organlarında Boğatepe gravyerini tanitan programlar yapılmakta ve gastronomi dergilerinde tanıtım yazıları çıkmaktadır. Bu girişim olumlu ancak yetersiz düzeydedir. Bütün olumsuzluklara rağmen Boğatepe köyünün Gravyer peyniri üretimi, örnek alınması ve yaygınlaştıııması gereken bir ekonomik faaliyettir. Ardahan-Kars Yöresinin kalkınması ve sürdürülebilir gelişmesi bakımından da önemlidir.

\section{Kaynakça}

Akça, B., Kıyanç, S. (2017). Malakanlar'ın Anadoludaki İzleri, Sosyal ve Beşeri Bilimler Araştirmaları Dergisi, Cilt:18, Sayı: 39, 22-43.

Arınç, K. (2016). Doğal, Beşeri, İktisadi ve Siyasal Yönleriyle Doğu ve Güneydoğu Bölgeleri, Biyosfer Araştırmaları Merkezi Yayınları No: 106, s.1-370, Erzurum. (ISBN: 978-605-61910-6-0).

Demir, M. (2016). Coğrafi İşaret Örneği Olarak Kars Kaşar Peynirinin Üretimi ve Dağılımı, Kafkas Üniversitesi, Sosyal Bilimler Enstitüsü Dergisi, Sayı No:1,61-81. DOI:10.9775/kausbed.2016.033

Demir, P., Adıgüzel, S.E., Sarı, M., ve Ayvazoğlu, C. (2014). Kars Merkez İlçedeki Süt Sığırcılık İşletmelerinin Genel Yapısı ve Ekonomik Boyutu, Fırat Üniversitesi, Sağlık Bilimleri Veterinerlik Dergisi, (28) 1 , 9-13.

Erinç, S. (1953). Doğu Anadolu Bölgesi Coğrafyası. İstanbul Üniversitesi Yayınları No: 572, Coğrafya Enstitüsü Yayınları No:15, İstanbul, 1124.

Eroğlu, D., Yılmaz, N., (2015), 'Effect of Gender Roles on Woman's ICT Use in Rural Turkey: A Case Study in Kars Prowince', International Journal of Humanities Social Sciences and Education. Volume 2, Issue 9, 153-158.

Gelibolu, L. (2009). Kars Kaşar Peyniri İ̧̧letmelerinin Pazarlama Sorunları ve Çözüm Önerileri Üzerine Bir Alan Araştrrması, Atatürk Üniversitesi, Iktisadi ve Idari Bilimler Fakültesi Dergisi, Cilt: 23, Sayı: 3, Erzurum, 151-165.

Göney, S. (1979). Siyasi Coğrafya, Cilt:2, İstanbul Üniversitesi Yayın No:2539, Coğrafya Enstitüsü Yayın No: 103, İstanbul, 1-175.

Güneş, F., Özhatay, N., (2011), 'An ethnobotanical study from Kars (Eastern) Turkey', Biological Diversity and Conversation, 4/1, 3041.

Kemaloğlu, M. (2012). Terekeme-Karapapak Türkleri Yerleşim Alanları, Uluslararası Türkçe Edebiyat Kültür Eğitim Dergisi, Sayı 1/3, p.5581.

Kırzıoğlu,F. (1953). Kars Tarihi. Işıl Matbaası, İstanbul.

Mankan, E.,(2017), 'Dünyadaki Gastronomi Müzeleri Üzerine Genel Bir Değerlendirme'. Turkish Studies International Periodical for the Languages, Literature and History of Turkish or Turkic Volume 12/1, p. 157-176. DOI Number: http://dx.doi.org/10.7827/TurkishStudies.11339 ISSN: 1308-2140, ANKARA-TURKEY.

Marshall, A.G. (2001). Dar-Al-Harb: the Russian general staff and the Asiatic frontier, 1860-1917. PhD thesis, University of Glasgow, 1267.

Ocakverdi, H. (2001). The Flora of the Mount Kısır (Kars and Ardahan) and Nearest Environs. TÜBITAK Türkish Journal of Botany. Volume 25, Number:5, 311-334. E-ISSN: 1303-6106, ISSN: 1300-008X.

Özşensoy, Y. (2011). Türkiye'de Bulunan Bazı Yerli Sığır Irklarının Genetik Yapılarının Karakterizasyonu. Selçuk Üniversitesi, Sağlık Bilimleri Enstitüsü, Yayımlanmamış Doktora Tezi, Konya, 1-134.

Savcı, G. (1980). Doğu Anadolu Volkanizmasının Neotektonik Önemi. Yeryuvarı ve Insan, Ağustos-Kasım 1980 Sayısı, Ankara, 46-49.

Seçkin, E. (2016). An Analysis of Selected Cases of Envıronmental Movements in Turkey Through an Ecofeminist Approach. The Graduate School of Natural and Applied Sciences of Middle East Technical University, The Master Thesis, Ankara, 1-153.

Semyenov, I.I, (2001). History of Caucasican Molokans and Dukhobors. Erevan, 1-120.

Süvari, Ç. C. (2013). Malakanlar: Rus-Köylü Hareketlerinden Günümüze Malakan İnancı. Ütopya Yayınevi, ISBN: 9786055580438, 1144.

Şaroğlu, F., Güner, Y. (1981). Doğu Anadolu'nun Jeomorfolojik Gelişimine Etki Eden Öğeler: Jeomorfoloji, Tektonik, Volkanizma İlişkileri. Türkiye Jeoloji Kurumu Bülteni, Sayı: 24, Ankara.

Tokel, S. (1984). Doğu Anadolu'da Kabuk Deformasyon Mekanizması ve Genç Volkanitlerin Petrojenezi. Ketin Sempozuyumu Bildiriler Kitabı, 121-131.

Topuk,Ş. (2014). Kars Gravyer Peynirlerinin Kalitelerinin Araştırılması. Kafkas Üniversitesi, Sağlık Bilimleri Enstitüsü, Yayımlanmamış Yük- 
sek Lisans Tezi, Kars.1-47.

Yıldız, S., Alp, S.(2014). Bir Kümelenme Örneği Olarak Kars Kaşar Peyniri Endüstri Kümesi. H.Ü. Iktisadi ve İdari Bilimler Fakültesi Dergisi, Cilt: 32, Sayı:1, 249-272. 